\title{
L-Type Calcium Channels Mediate Calcium Oscillations in Early Postnatal Purkinje Neurons
}

\author{
Patricia Liljelund, Jeffrey G. Netzeband, and Donna L. Gruol \\ Department of Neuropharmacology, The Scripps Research Institute, La Jolla, California 92037
}

\begin{abstract}
$\mathrm{Ca}^{2+}$ signaling is important in many fundamental neuronal processes including neurotransmission, synaptic plasticity, neuronal development, and gene expression. In cerebellar Purkinje neurons, $\mathrm{Ca}^{2+}$ signaling has been studied primarily in the dendritic region where increases in local $\mathrm{Ca}^{2+}$ have been shown to occur with both synaptic events and spontaneous electrical activity involving $\mathrm{P}$-type voltage-gated $\mathrm{Ca}^{2+}$ channels (VGCCs), the predominant VGCC expressed by Purkinje neurons. Here we show that $\mathrm{Ca}^{2+}$ signaling is also a prominent feature of immature Purkinje neurons at developmental stages that precede expression of dendritic structure and involves L-type rather than P-type VGCCs. Immature Purkinje neurons acutely dissociated from postnatal day 4-7 rat pups exhibit spontaneous cytoplasmic $\mathrm{Ca}^{2+}$ oscillations. The $\mathrm{Ca}^{2+}$ oscillations require entry of extracellular $\mathrm{Ca}^{2+}$, are blocked by tetrodotoxin, are communicated to the nucleus, and correlate closely with patterns of endogenously
\end{abstract}

generated spontaneous and evoked electrical activity recorded in the neurons. Immunocytochemistry showed that L-, N-, and $P / Q$-types of VGCCs are present on the somata of the Purkinje neurons at this age. However, only the L-type VGCC antagonist nimodipine effectively antagonized the $\mathrm{Ca}^{2+}$ oscillations; inhibitors of $P / Q$ and N-type VGCCs were relatively ineffective. Release of $\mathrm{Ca}^{2+}$ from intracellular $\mathrm{Ca}^{2+}$ stores significantly amplified the $\mathrm{Ca}^{2+}$ signals of external origin. These results show that a somatic signaling pathway that generates intracellular $\mathrm{Ca}^{2+}$ oscillations and involves L-type VGCCs and intracellular $\mathrm{Ca}^{2+}$ stores plays a prominent role in the $\mathrm{Ca}^{2+}$ dynamics of early developing Purkinje neurons and may play an important role in communicating developmental cues to the nucleus.

Key words: cerebellum; development; acutely isolated neurons; $\mathrm{Ca}^{2+}$ signaling; nuclear $\mathrm{Ca}^{2+}$; intracellular $\mathrm{Ca}^{2+}$ stores
Cerebellar Purkinje neurons are a favored model for studying $\mathrm{Ca}^{2+}$ signaling because of the prominent role played by $\mathrm{Ca}^{2+}$ in dendritic excitability and synaptic transmission in this neuronal type (Tank et al., 1988; Hockberger et al., 1989; Gruol et al., 1992; Miyakawa et al., 1992; Eilers et al., 1996). In mature Purkinje neurons, dendritic voltage-gated $\mathrm{Ca}^{2+}$ channels (VGCCs), predominantly the P-type (Hillman et al., 1991), have been shown to mediate changes in dendritic $\mathrm{Ca}^{2+}$ levels associated with spontaneous or evoked electrical activity (Tank et al., 1988; Sugimori and Llinas, 1990). In addition, stimulation of either climbing fibers or parallel fibers, the excitatory afferents to Purkinje neurons, produces local increases in dendritic $\mathrm{Ca}^{2+}$ via activation of glutamate receptors and VGCCs (Ross and Werman, 1987; Sugimori and Llinas, 1990; Konnerth et al., 1992; Miyakawa et al., 1992; Eilers et al., 1995). Release of $\mathrm{Ca}^{2+}$ from intracellular $\mathrm{Ca}^{2+}$ stores also contributes to $\mathrm{Ca}^{2+}$ signaling in Purkinje neuron dendrites and is mediated both by ryanodine receptors (RyR) and inositol-1,4,5trisphosphate receptors (IP3R) (Kano et al., 1995a; Gruol et al., 1996; Finch and Augustine, 1998; Narasimhan et al., 1998).

$\mathrm{Ca}^{2+}$ signaling is also an important physiological property of developing neurons, but relatively little is known about this process in immature Purkinje neurons. Components essential for $\mathrm{Ca}^{2+}$ signaling in Purkinje neuron dendrites are expressed early in Purkinje neuron development, when Purkinje neurons are structurally relatively simple and consist primarily of a somata and axon with little or no dendritic structure. These $\mathrm{Ca}^{2+}$-signaling components included VGCCs, RyRs, IP3Rs, and the $\mathrm{Ca}^{2+}$-binding proteins

Received Jan. 11, 2000; revised July 10, 2000; accepted July 19, 2000.

This work was supported by National Institute on Alcohol Abuse and Alcoholism Training Grant AA07456-17, RO1 AA06665, and RO1 AA06420 to the Alcohol Center. We thank Gilles Martin for generously sharing his protocol for acute isolation of neurons, Lely Quina for her assistance in adapting the method for Purkinje neurons, and Jaimes Schneeloch for assistance with electrophysiological studies. We are also grateful to Floriska Chizer-Slack for secretarial help and Novartis for the gift of CGP55845A.

Correspondence should be addressed to Dr. Donna L. Gruol, Department of Neuropharmacology, CVN 11, The Scripps Research Institute, 10550 North Torrey Pines Road, La Jolla, CA 92037. E-mail: gruol@scripps.edu.

Copyright (C) 2000 Society for Neuroscience $0270-6474 / 00 / 207394-10 \$ 15.00 / 0$ calbindin and parvalbumin (Gruol and Franklin, 1987; Regan, 1991; Gruol et al., 1992; Mintz et al., 1992; Llano et al., 1994; Milosevic and Zecevic, 1998). Large $\mathrm{Ca}^{2+}$ transients can be experimentally evoked in early postnatal Purkinje neurons (Kano et al., 1995b), indicating the functional capacity for $\mathrm{Ca}^{2+}$ signaling. However, the relationship between this capacity and the physiology of the immature Purkinje neurons is unknown. Physiological events associated with dendritic $\mathrm{Ca}^{2+}$ signaling in mature Purkinje neurons are expressed at the somatic level in early developing Purkinje neurons including endogenously generated electrical activity and excitatory synaptic input (Woodward et al., 1969a,b; Gruol and Franklin, 1987; Mason et al., 1990; Gruol et al., 1991; Altman and Bayer, 1997), but the potential role of this activity in $\mathrm{Ca}^{2+}$ signaling has not been investigated.

In the current study we investigated $\mathrm{Ca}^{2+}$ dynamics in early developing Purkinje neurons acutely isolated from the cerebella of postnatal rats. Results show that immature Purkinje neurons exhibit spontaneous somatic $\mathrm{Ca}^{2+}$ oscillations that are generated by endogenous electrical activity, amplified via release of $\mathrm{Ca}^{2+}$ from intracellular stores, and transmitted to the nucleus. The $\mathrm{Ca}^{2+}$ oscillations occur via a signaling pathway involving L-type VGCCs rather than P-type VGCCs, which mediate the electrically evoked $\mathrm{Ca}^{2+}$ signals of Purkinje neuron dendrites (Usowicz et al., 1992). In addition to playing an important role in regulating $\mathrm{Ca}^{2+} \mathrm{dy-}$ namics of immature Purkinje neurons, this signaling pathway may contribute to the early developmental program by influencing downstream events such as gene expression.

\section{MATERIALS AND METHODS}

Preparation of acutely dissociated cerebellar cells. Purkinje neurons were acutely isolated from postnatal rats according to the methods of Surmeier et al. (1991). Rat pups between the ages of postnatal day 4 (P4) and P7 were rapidly decapitated, and the cerebellum was immediately removed and kept moistened with ice-cold, oxygenated artificial CSF (in mM: 130 $\mathrm{NaCl}, 3.5 \mathrm{KCl}, 1.25 \mathrm{NaH}_{2} \mathrm{PO}_{4}, 24 \mathrm{NaHCO}_{3}, 10$ glucose, $0.2 \mathrm{CaCl}_{2}$, and 5.0 $\left.\mathrm{MgSO}_{4}\right)$. The meninges were dissected away, 350-450 $\mu \mathrm{m}$ sagittal slices were cut manually from the vermis, and the white matter was removed under a dissecting microscope. Slices were minced in isethionate buffer (in mM: 140 sodium isethionate, $2 \mathrm{KCl}, 4 \mathrm{MgCl}_{2}, 23$ glucose, and $15 \mathrm{HEPES}$, $\mathrm{pH}$ adjusted to 7.4 with $\mathrm{NaOH}$ ) supplemented with $5 \mu \mathrm{M}$ glutathione, $1 \mathrm{~mm}$ 
$N$ - $\omega$-nitro-L-arginine, and $10 \mathrm{~mm}$ kynurenic acid at room temperature $\left(21-23^{\circ} \mathrm{C}\right)$. The tissue was incubated $45 \mathrm{~min}$ in Earl's Balanced Salt Solution (supplemented as above) in a spinner flask in the presence of $5 \%$ $\mathrm{CO}_{2}$ and $95 \% \mathrm{O}_{2}$ at room temperature. The tissue was then incubated for 30 min with $0.1 \%$ papain (Sigma, St. Louis, MO) in HBSS (supplemented as above) in an oxygenated spinner flask maintained at $37^{\circ} \mathrm{C}$. The tissue was washed three times in isethionate buffer (see composition above) and gently triturated through a size series of three fire-polished Pasteur pipettes to dissociate the tissue and isolate the cells. Cells were plated on Lab-Tek chamber slides (Nunc, Naperville, IL) for immunological studies or glass coverslips (Fisher Scientific, Houston, TX) for physiological recordings. Experiments were performed in physiological saline (in mM: 140 $\mathrm{NaCl}, 3.5 \mathrm{KCl}, 0.4 \mathrm{KH}_{2} \mathrm{PO}_{4}, 1.25 \mathrm{Na}_{2} \mathrm{HPO}_{4}, 2.2 \mathrm{CaCl}_{2}, 2 \mathrm{MgSO}_{4}, 10$ glucose, and 10 HEPES, pH-adjusted to 7.3 with $\mathrm{NaOH}$ ) or $\mathrm{Mg}^{2+}$-free saline supplemented with $5 \mu \mathrm{M}$ glycine depending on the experiment.

Measurement of $\mathrm{Ca}^{2+}$ levels. Dissociated cells were centrifuged to pellet them $(5 \mathrm{~min}$ at $6000 \mathrm{rpm})$ and loaded with the fluorescent $\mathrm{Ca}^{2+}$ indicator fura-2 AM (Molecular Probes, Eugene, OR) by resuspending the cells in physiological saline (see composition above) containing $3 \mu \mathrm{M}$ fura- 2 and $0.02 \%$ pluronic F-127 (Molecular Probes) for $30 \mathrm{~min}$ in the dark at room temperature $\left(21-23^{\circ} \mathrm{C}\right)$. Cells were then centrifuged and resuspended in physiological saline. The cell suspension was plated on glass coverslips that had been precoated overnight at $4^{\circ} \mathrm{C}$ with Thy 1 antibody $(100 \mu \mathrm{g} / \mathrm{ml}$; Sigma), washed once with PBS, and incubated in physiological saline during the attachment period. Poly-L-lysine (Sigma) and Matrigel (Collaborative Biomedical Products, Bedford, MA) were also tested as substrates, but Thy1 antibody-coated glass coverslips were found to most effectively immobilize the Purkinje neurons (Baptista et al., 1994). Results were not dependent on the relative plating density or substrate used. Coverslips with fura-2-loaded cells were used for experiments $1 \mathrm{hr}$ after plating.

Standard microscopic fura-2 digital imaging techniques were used as described previously (Gruol et al., 1996). Neurons were viewed with a Nikon Eclipse TE300 inverted fluorescent microscope and light intensity monitored with a silicon-intensifier target camera (SITCAM) (MTI VE1000SIT; Dage, Michigan City, IN) for capturing live video images. Data were collected at $2-5 \mathrm{sec}$ intervals (four frames per wavelength were averaged for each time point) over a total time of $90 \mathrm{sec}$ to $10 \mathrm{~min}$ depending on the experiment. Ratio images of individual neurons in each field were formed by pixel-by-pixel division of the averaged images col- lected at 340 and $380 \mathrm{~nm}(340 / 380 \mathrm{~nm})$. Real-time digitized display, image acquisition, and calculation of intracellular $\mathrm{Ca}^{2+}$ levels were made with Microcomputer Imaging Device imaging software (Imaging Research, St. Catharines, Ontario). Intracellular $\mathrm{Ca}^{2+}$ levels were estimated using the following formula: $\left[\mathrm{Ca}^{2+}\right]_{\mathrm{i}}=K_{\mathrm{d}}\left(R-R_{\min }\right) /\left(R_{\max }-\right.$ $R)^{*} F_{\mathrm{o}} / F_{\mathrm{s}}$, where $R$ is the ratio value, $R_{\min }$ is the ratio for a $\mathrm{Ca}^{2+}$ free solution, $R_{\max }$ is the ratio for a saturated $\mathrm{Ca}^{2+}$ solution, $K_{\mathrm{d}}$ is 135 (the dissociation constant for fura-2), $F_{\mathrm{o}}$ is the intensity of a $\mathrm{Ca}^{2+}$-free solution at $380 \mathrm{~nm}$, and $F_{\mathrm{s}}$ is the intensity of a saturated $\mathrm{Ca}^{2+}$ solution at $380 \mathrm{~nm}$. $R_{\min }$ and $R_{\max }$ values were determined from standardized solutions of known $\mathrm{Ca}^{2+}$ concentration (Molecular Probes calibration kit C-3009) containing fura salt $(100 \mu \mathrm{M})$. Calculated levels of intracellular $\mathrm{Ca}^{2+}$ obtained by this method are considered approximations and are used primarily to provide information about the relative level of intracellular $\mathrm{Ca}^{2+}$ under a variety of experimental conditions. Typical $R_{\max }, R_{\min }$, and $F_{\mathrm{o}} / F_{\text {s }}$ values were $0.61,2.85$, and 2.5 , respectively. The low level of background fluorescence and adjustment of the black level of the SITCAM eliminated the need for background subtraction methods. Measurements were made of baseline $\mathrm{Ca}^{2+}$ levels, the maximum amplitude of the $\mathrm{Ca}^{2+}$ oscillations relative to baseline, and the average $\mathrm{Ca}^{2+}$ level above baseline (see Fig. 2B). Baseline for a neuron was defined as the lowest $\mathrm{Ca}^{2+}$ level observed in the $\mathrm{Ca}^{2+}$ recording.

Drugs. Experiments were performed in the presence of $5 \mu \mathrm{M}$ 2,3-dioxo6-nitro-1,2,3,4-tetrahydrobenzo[f]quinoxaline-7-sulfonamide disodium (Tocris Cookson, Langford, Bristol, UK), $100 \mu \mathrm{M}$ picrotoxin (Sigma), and $1 \mu \mathrm{M}$ CGP55845A (Novartis, Basel, Switzerland) in the bath saline to block AMPA, GABA ${ }_{A}$, and $\mathrm{GABA}_{\mathrm{B}}$ receptors, respectively. Test agents were diluted in bath saline and introduced by bath addition or bath exchange to achieve the desired concentrations. A variety of drugs were tested including the P-type VGCC antagonist $\omega$-agatoxin IVA $(0.1 \mu \mathrm{M}$; Calbiochem, $\mathrm{La}$ Jolla, CA), the N-type VGCC antagonist $\omega$-conotoxin GVIA $(1 \mu \mathrm{M}$; Calbiochem), the L-type VGCC antagonist nimodipine (1 $\mu \mathrm{M}$; Research Biochemicals International, Natick, MA), the competitive NMDA receptor antagonist APV $(50 \mu \mathrm{M}$; Tocris), the NMDA receptor open channel blocker 5R,10S)-(+)-5-methyl-10,11-dihydro-5H-dibenzo[a,d]-cyclohepten5,10-imine/dizocilpine (MK801; $10 \mu \mathrm{M}$; Tocris), the sodium channel inhibitor tetrodotoxin (TTX; $0.5 \mu \mathrm{M}$; Calbiochem), and the dihydropyridine receptor agonist $S(-)$-BayK-8644 (1 $\mu \mathrm{M}$; Research Biochemicals International). Stock solutions of nimodipine and BayK-8644 were prepared in DMSO.
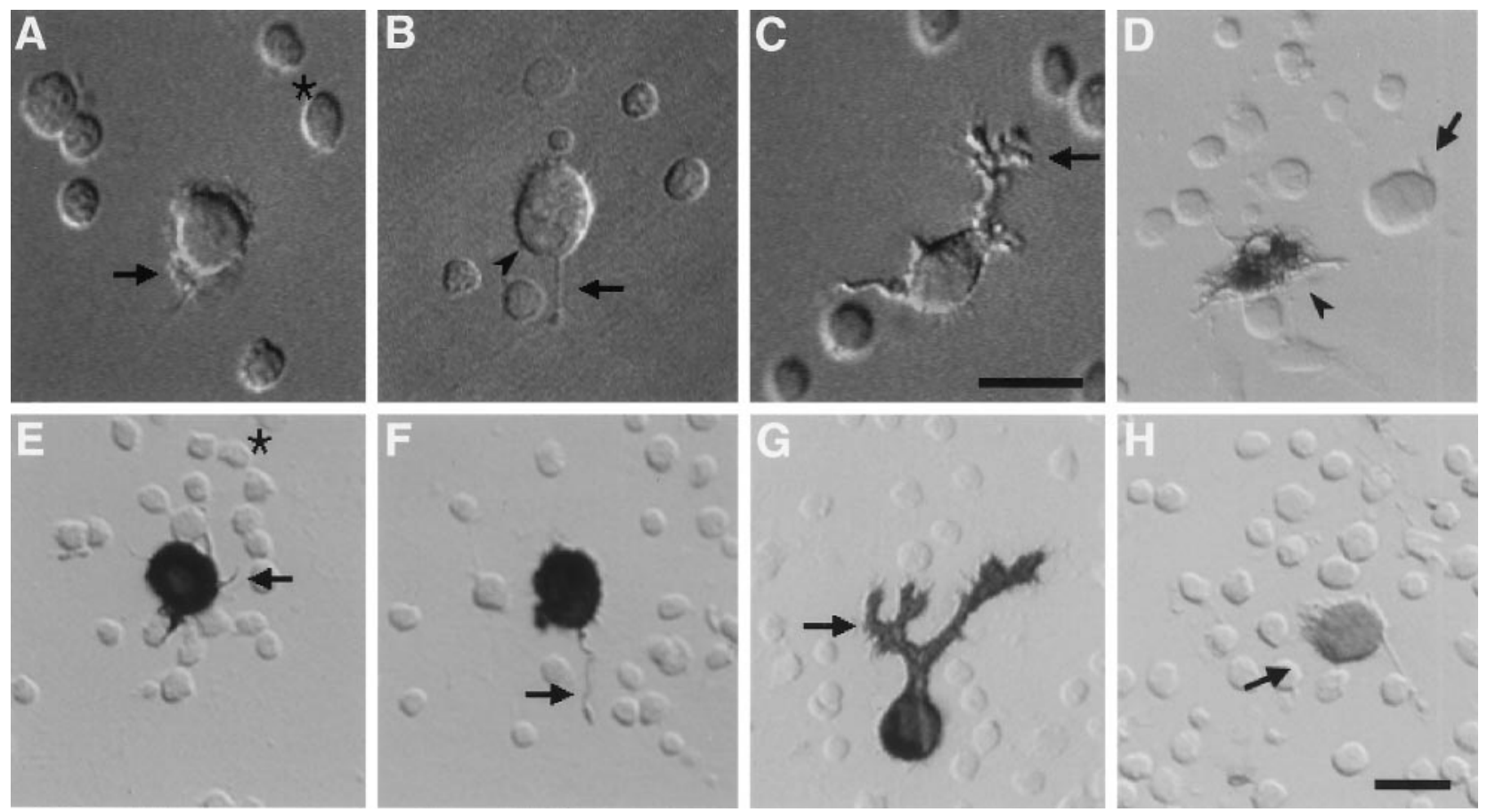

Figure 1. Morphological and immunological characteristics of acutely isolated immature Purkinje neurons. $A-C$, Live Purkinje neurons photographed under high power (Nomarski optics) to illustrate features of early developing Purkinje neurons at P4 $(A)$ to $\mathrm{P} 7(B, C)$. $A$, Perisomatic processes (arrow) were characteristic of Purkinje neurons early in development (P4). The asterisk indicates granule neurons that were present in all microscopic fields. $B$, A short axon (arrow) and prominent lateralized nucleus (arrowhead) were generally evident at P7. $C$, The initial outgrowth of the apical dendritic tree (arrow) was occasionally seen at P7. It should be noted, however, that a variety of morphological forms could be found within any given preparation because the cerebellar folia mature at different rates. D, Glial cell (arrowhead) immunostained with an antibody to GFAP. Arrow points to an unstained Purkinje neuron. As noted for acutely prepared P7 to P14 cerebellum (Hockberger et al., 1994), we found that some glial cells resembled Purkinje neurons, especially at the earliest stage studied. However, preliminary removal of the white matter during the dissection significantly reduced the number of glial cells. $E-G$, Purkinje neurons immunostained with an antibody to calbindin, a specific marker for Purkinje neurons (Enderlin et al., 1987). Arrows in $E-G$ correspond to the structures labeled in $A-C$, respectively. Granule neurons ( $E$, asterisk) did not immunostain for calbindin. $H$, Purkinje neuron (arrow) immunostained with an antibody to GABA, the neurotransmitter used by Purkinje neurons. Granule neurons, which use glutamate as a neurotransmitter, were unstained. All immunostaining was photographed using Hoffman optics. Scale bars: $C, H, 15 \mu \mathrm{m}$ (refer to $A-C$ and $D-H$, respectively). 
DMSO by itself did not affect spontaneous $\mathrm{Ca}^{2+}$ oscillations (data not shown). In most studies at least three different cell preparations were tested to determine the effect of a given drug. $n$ is the number of cells studied. Results are presented as mean \pm SEM.

Electrophysiological techniques. Electrophysiological recordings were performed in combination with recordings of intracellular $\mathrm{Ca}^{2+}$ or in parallel with $\mathrm{Ca}^{2+}$-imaging studies (see above). Current-clamp recordings were made from the somatic region of acutely isolated Purkinje neurons using the nystatin, perforated-patch method of whole-cell recording and the Axopatch-1C amplifier (Axon Instruments, Foster City, CA) following previously described methods (Netzeband et al., 1997). Briefly, patch pipettes $(2-4 \mathrm{M} \Omega)$ were filled with a pipette solution containing $6 \mathrm{~mm}$ $\mathrm{NaCl}, 154 \mathrm{~mm} \mathrm{~K}^{+}$-gluconate, $10 \mathrm{~mm} \mathrm{HEPES}$, and $200 \mu \mathrm{g} / \mathrm{ml}$ nystatin (Sigma), $\mathrm{pH}$ adjusted to 7.3 with $\mathrm{KOH}$. A stock solution of nystatin (50 $\mathrm{mg} / \mathrm{ml}$ DMSO) was prepared fresh for each experiment and diluted in the pipette solution. Recordings were made at the resting membrane potential of the cell and monitored on a polygraph (Gould, West Warwick, RI) and oscilloscope. For better resolution of fast events, selected data were recorded on FM tape (Store 4DS; Racal Recorders, Irvine, CA) for playback at reduced tape speed onto the polygraph recorder. Voltage responses elicited by a standardized series of hyperpolarizing and depolarizing current pulses (500 msec duration) were used to assess membrane properties. pClamp software and the Labmaster interface (Axon Instruments) were used for acquisition and analysis of the current-evoked membrane responses. All recordings were made at room temperature.

Immunohistochemistry. The acutely dissociated cerebellar cells were immunostained according to standard methods (Netzeband et al., 1997) Cells were fixed for $15 \mathrm{~min}$ in $4 \%$ paraformaldehyde (or $4 \%$ paraformaldehyde and $0.1 \%$ glutaraldehyde for GABA immunostaining) and washed three times (10 min) with 5\% sucrose in PBS and once with PBS (10 min). The cells were then incubated $30 \mathrm{~min}$ in PBS containing $0.05 \%$ Triton $\mathrm{X}-100$, followed by three washes $(10 \mathrm{~min})$ in PBS. Primary antibodies were diluted in PBS with $0.5 \mathrm{mg} \mathrm{BSA} / \mathrm{ml}$ and $1 \%$ serum and incubated overnight at $4^{\circ} \mathrm{C}$. The following antibodies were used: mouse monoclonal anticalbindin (1:3000; Sigma); mouse monoclonal anti-glial fibrillary acidic protein (GFAP) (1:2000; Boehringer Mannheim, Indianapolis, IN); rabbit polyclonal anti-GABA (1:500; Incstar, Stillwater, MN); rabbit polyclonal anti- $\alpha_{1 \mathrm{~A}}$ subunit of P/Q-type VGCC (1:1000; Alomone Labs, Jerusalem, Israel); rabbit polyclonal anti- $\alpha_{18}$ subunit of N-type VGCC (1:500; Alomone Labs); and rabbit polyclonal anti-rat $\alpha_{1 \mathrm{C}}$ subunit of L-type VGCC (1:1000; Alomone Labs). Vectastain kits (Vector Laboratories, Burlingame, CA) were used for the secondary antibodies and the peroxidase reaction.

\section{RESULTS}

\section{Developing Purkinje neurons show spontaneous $\mathrm{Ca}^{2+}$ oscillations}

The experiments focused on the postnatal age interval between $\mathrm{P} 4$ and P7 (Fig. $1 A-C$ ), known to represent a small but significant time window of Purkinje neuron development that precedes the main period of dendritic elaboration and synapse formation (Altman, 1972). Purkinje neurons in cerebellar cell preparations obtained by acute dissociation of $\mathrm{P} 4$ to $\mathrm{P} 7$ rat cerebella were identified for study by morphological criteria established by immunostaining cerebellar cell preparations with an antibody to the $\mathrm{Ca}^{2+}$-binding protein calbindin (Fig. $1 E-G$ ), a marker for Purkinje neurons (Enderlin et al., 1987). Morphologically identified Purkinje neurons also immunostained with an antibody to GABA (Fig. $1 H$ ), the neurotransmitter used by Purkinje neurons, but did not immunostain with an antibody to GFAP (Fig. 1D), a marker for glial cells. Granule neurons, cerebellar interneurons that use glutamate as a transmitter, were identified by their small, uniform size and lack of immunoreactivity for antibodies to calbindin, GABA, and GFAP (Fig. 1).

Measurement of intracellular $\mathrm{Ca}^{2+}$ levels in the immature Purkinje neurons revealed that they exhibit sustained spontaneous oscillations of intracellular $\mathrm{Ca}^{2+}$ (Fig. 2) and that such activity is present as early as $4 \mathrm{~d}$ after birth, the earliest age examined. To obtain an overview of the patterns of spontaneous $\mathrm{Ca}^{2+}$ activity, collections of 5 or $10 \mathrm{~min}$ at $5 \mathrm{sec}$ intervals were performed on oscillating Purkinje neurons isolated from P4 to P7 rat pups. Patterns of $\mathrm{Ca}^{2+}$ oscillation were fairly consistent for a given Purkinje neuron but were highly variable among Purkinje neurons at all ages studied. Figure 2 illustrates three typical patterns of $\mathrm{Ca}^{2+}$ oscillations observed in the Purkinje neurons. The average frequency of $\mathrm{Ca}^{2+}$ oscillations was measured as the number of peaks occurring during the recording period. The average frequency for a population of P4 to P7 neurons studied was $2.6 \pm 0.1$ oscillations/min $(n=24)$, a rate significantly higher than, for
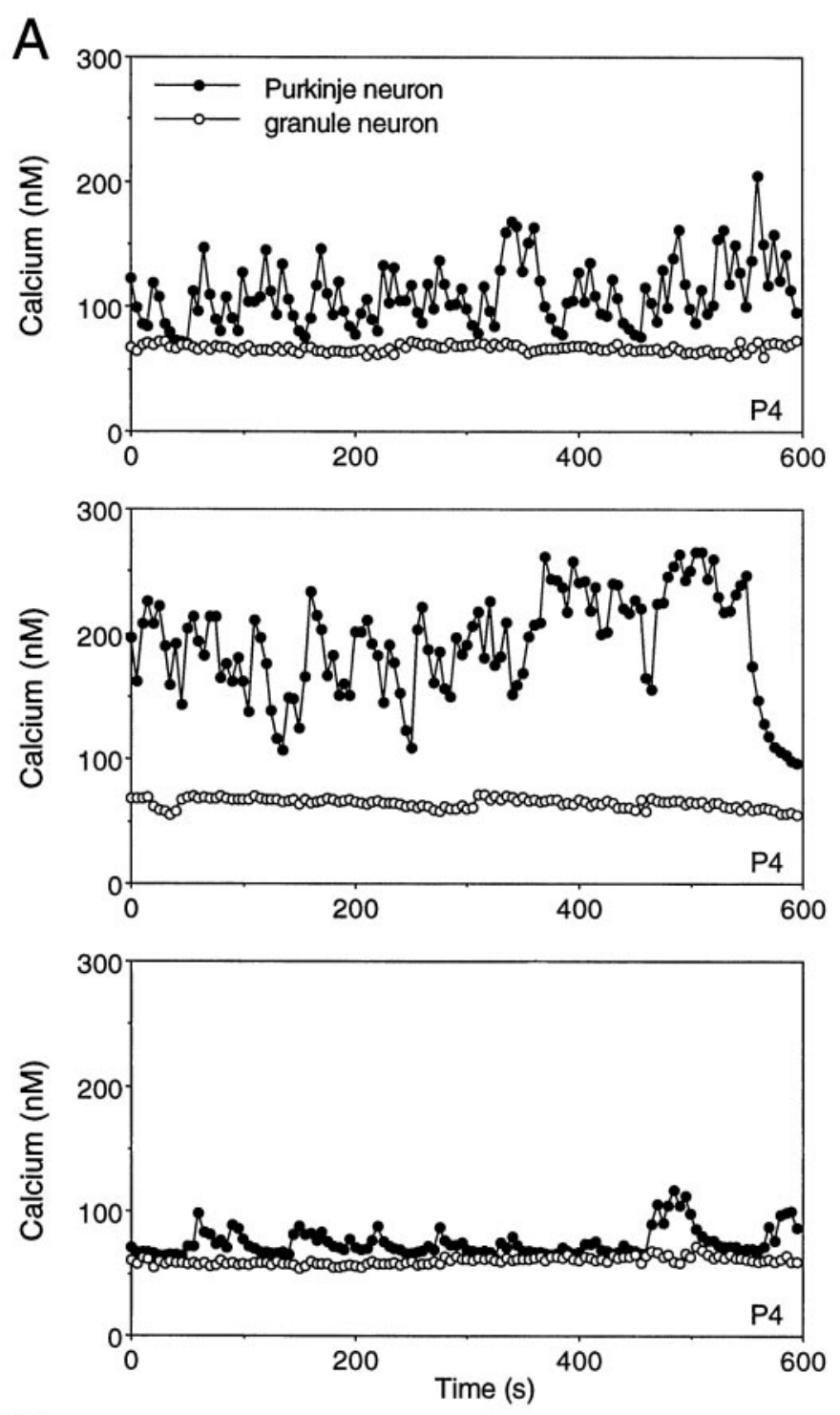

B

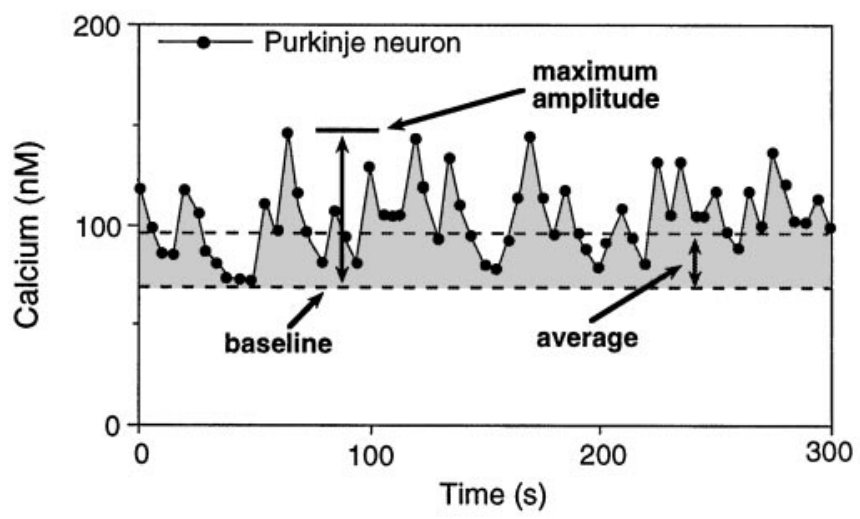

Figure 2. Early postnatal Purkinje neurons exhibit spontaneous oscillations of intracellular $\mathrm{Ca}^{2+}$ levels. $A, \mathrm{Ca}^{2+}$ recordings from three representative Purkinje neurons; spontaneous $\mathrm{Ca}^{2+}$ oscillations persisted throughout the entire recording period. A granule neuron is included in each example for comparison; $\mathrm{Ca}^{2+}$ oscillations were small or absent in granule neurons (see also Figs. 4, 6, and 7). Collections were performed at $5 \mathrm{sec}$ intervals for $10 \mathrm{~min}$. The animal age is indicated in the bottom right-hand corner. B, Quantification of $\mathrm{Ca}^{2+}$ oscillations. Measurements were made using Axograph software (Axon Instruments). The baseline $\mathrm{Ca}^{2+}$ level was defined as the lowest $\mathrm{Ca}^{2+}$ level measured in a neuron. The highest $\mathrm{Ca}^{2+}$ level relative to baseline was defined as the maximum amplitude. Average amplitude was measured as the average $\mathrm{Ca}^{2+}$ level above baseline calculated over the recording period. 
Table 1. Descriptive characteristics of spontaneous $\mathrm{Ca}^{2+}$ transients observed in Purkinje neurons

\begin{tabular}{|c|c|c|c|c|c|c|}
\hline \multirow[b]{2}{*}{ Age } & \multicolumn{2}{|c|}{ Non-oscillating cells } & \multicolumn{4}{|c|}{ Oscillating cells } \\
\hline & $n$ & Baseline $\mathrm{Ca}^{2+}(\mathrm{nm})$ & $n$ & Baseline $\mathrm{Ca}^{2+}(\mathrm{nM})$ & Maximum amplitude (nM) & Average $\mathrm{Ca}^{2+}(\mathrm{nM})$ \\
\hline $\mathrm{P} 4$ & 21 & $54 \pm 6$ & 82 & $48 \pm 3$ & $85 \pm 8$ & $29 \pm 3$ \\
\hline P5 & 33 & $61 \pm 2$ & 79 & $62 \pm 2^{*}$ & $47 \pm 5^{*}$ & $16 \pm 2 *$ \\
\hline P6 & 50 & $54 \pm 3$ & 95 & $61 \pm 3^{*}$ & $49 \pm 6^{*}$ & $20 \pm 2^{*}$ \\
\hline P7 & 28 & $61 \pm 3$ & 94 & $68 \pm 2 * * *$ & $56 \pm 5^{*}$ & $22 \pm 2 *, * *$ \\
\hline
\end{tabular}

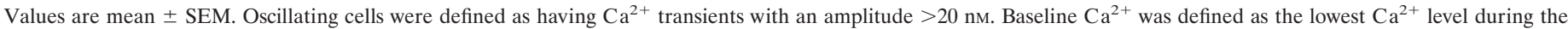

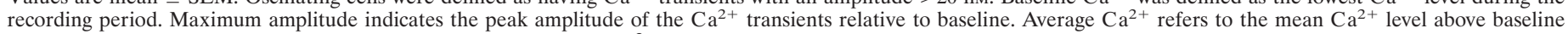
during the recording period. Data were based on measurement of $\mathrm{Ca}^{2+}$ levels during collections of $1-5$ min at 3-5 sec intervals.

*Significant difference compared with the corresponding value at P4 ( $p<0.05$; ANOVA; post hoc analysis by Fisher's protected least significant difference test).

** Significant difference compared with the corresponding value at P5 ( $p<0.05$; ANOVA; post hoc analysis by Fisher's protected least significant difference test).

example, that measured for spontaneous $\mathrm{Ca}^{2+}$ spikes $(2.4 \pm 0.3$ spikes/hr) and waves $(2.1 \pm 0.2$ waves/hr) in embryonic Xenopus spinal neurons ( $\mathrm{Gu}$ et al., 1994) or for spontaneous $\mathrm{Ca}^{2+}$ fluctuations in the leading process of migrating cerebellar granule cells (13 \pm 3 fluctuations/hr; Komuro and Rakic, 1996).

Statistics on various measures of the $\mathrm{Ca}^{2+}$ oscillations at different ages were obtained from collections of $1-5 \mathrm{~min}$ at $3-5 \mathrm{sec}$ intervals. Measurements were made of baseline $\mathrm{Ca}^{2+}$ levels, the maximum amplitude of the $\mathrm{Ca}^{2+}$ oscillations relative to baseline, and the average $\mathrm{Ca}^{2+}$ level above baseline (Fig. $2 B$ ). The minimum amplitude (relative to baseline) for defining an oscillation was $20 \mathrm{~nm}$. Approximately two-thirds (219 of 351 cells) of the P4 to P7 Purkinje neurons studied displayed oscillations in $\mathrm{Ca}^{2+}$ levels. In oscillating cells, age-related differences were observed in all measurements with the most prominent changes occurring between $\mathrm{P} 4$ and P5, when a significant increase in baseline $\mathrm{Ca}^{2+}$ and decrease in maximum amplitude and average $\mathrm{Ca}^{2+}$ were observed (Table 1). In nonoscillating cells, measurements were made of baseline $\mathrm{Ca}^{2+}$ levels, which showed no significant change between P4 and P7 (Table 1).

\section{Nuclear $\mathbf{C a}^{2+}$ changes}

In the above studies, the intracellular $\mathrm{Ca}^{2+}$ levels represent an average of levels measured over the entire somata of the neurons. However, in a subpopulation of the neurons studied $(n=20)$ the nuclear and cytoplasmic regions were clearly distinguishable, enabling measurements of these two subcellular regions. This analysis indicated that a pattern of $\mathrm{Ca}^{2+}$ oscillations similar to that observed in the cytoplasmic region occurred in the nuclear region (Fig. 3). Baseline $\mathrm{Ca}^{2+}$ levels were typically lower $(24 \pm 4 \%)$ in the nucleus compared with the cytoplasm. However, the maximum amplitude of the $\mathrm{Ca}^{2+}$ oscillations in the nucleus and cytoplasm were comparable. Mean values for the 20 neurons studied were $103 \pm 20 \mathrm{~nm}$ and $119 \pm 28 \mathrm{~nm}$ for the maximum amplitude of the nuclear and cytoplasmic $\mathrm{Ca}^{2+}$ oscillations, respectively.

\section{Generation of $\mathrm{Ca}^{2+}$ oscillations requires spontaneous electrical activity}

Mature Purkinje neurons in vivo exhibit spontaneous electrical activity generated both by synaptic input and endogenous voltagesensitive ionic mechanisms. This activity is expressed early in the developmental program (Woodward et al., 1969a,b; Gruol and Franklin, 1987). The acutely isolated Purkinje neurons are dissociated from their synaptic connections, making it unlikely that synaptic components contribute to the generation of the $\mathrm{Ca}^{2+}$ oscillations observed in the current study. However, several studies have shown that the endogenously generated component of the electrical activity is retained in acutely isolated Purkinje neurons (Nam and Hockberger, 1997; Raman and Bean, 1997, 1999). To determine whether the endogenously generated electrical activity plays a role in the generation of the $\mathrm{Ca}^{2+}$ oscillations, we tested the effect of TTX, which blocks the endogenously generated electrical activity of Purkinje neurons (Gruol and Franklin, 1987; Nam and Hockberger, 1997), on the $\mathrm{Ca}^{2+}$ oscillations. TTX $(1 \mu \mathrm{M})$ com- pletely abolished the $\mathrm{Ca}^{2+}$ oscillations, indicating an underlying involvement of $\mathrm{Na}^{+}$-dependent electrical activity in the generation of the $\mathrm{Ca}^{2+}$ transients (Fig. 4). TTX also blocked all spike activity recorded under current clamp (data not shown).

To examine the relationship between the spontaneous electrical activity and the $\mathrm{Ca}^{2+}$ oscillations, whole-cell (perforated patch), current-clamp recordings combined with $\mathrm{Ca}^{2+}$ imaging were performed on acutely isolated Purkinje neurons. In most cases, Purkinje neurons showing spontaneous $\mathrm{Ca}^{2+}$ oscillations were selected for study. The majority of Purkinje neurons studied $(n=11$ of 13) exhibited sustained spontaneous electrical activity composed of single and doublet spikes with intervening quiescent periods of varying length, patterns similar to that reported by others for acutely isolated Purkinje neurons of similar postnatal age (Nam and Hockberger, 1997) and immature Purkinje neurons in vivo (Woodward et al., 1969a,b) and in culture (Gruol and Franklin, 1987). Spontaneous $\mathrm{Ca}^{2+}$ oscillations correlated closely with the spontaneous electrical firing pattern in the combined recordings (Fig. 5A; see also Fig. 7). Moreover, manipulation of the endogenous electrical activity by applying hyperpolarizing or depolarizing current (Fig. $5 B$ ) produced a corresponding alteration in the $\mathrm{Ca}^{2+}$ oscillations, whereas in nonoscillating neurons depolarization of the membrane potential to elicit electrical activity produced $\mathrm{Ca}^{2+}$ signals similar to the spontaneous $\mathrm{Ca}^{2+}$ oscillations. Sustained electrical activity elevated resting $\mathrm{Ca}^{2+}$ levels because of summation of $\mathrm{Ca}^{2+}$ signals (Fig. $5 B$ ).

\section{$\mathrm{Ca}^{2+}$ oscillations require $\mathrm{Ca}^{2+}$ entry mediated by L-type VGCCs}

The correlation of electrical activity with the $\mathrm{Ca}^{2+}$ oscillations suggests that $\mathrm{Ca}^{2+}$ influx plays a primary role in the generation of the $\mathrm{Ca}^{2+}$ signals. To test for a dependence on $\mathrm{Ca}^{2+}$ influx, extracellular $\mathrm{Ca}^{2+}$ was reduced from $1.5 \mathrm{~mm}$ to $20 \mu \mathrm{M}$ with EGTA (1 $\mathrm{mm})$ in the bath saline. The $\mathrm{Ca}^{2+}$ oscillations were completely blocked by the reduction of extracellular $\mathrm{Ca}^{2+}(n=3$ from two preparations; Fig. $6 \mathrm{~A}$ ), indicating that influx of $\mathrm{Ca}^{2+}$ was required for the oscillations.

The two major avenues for $\mathrm{Ca}^{2+}$ entry into the neuron are through ligand-gated channels permeable to $\mathrm{Ca}^{2+}$ or through VGCCs. We first determined whether $\mathrm{Ca}^{2+}$ was entering through NMDA receptors because at this stage of development Purkinje neurons express NMDA receptors (Garthwaite et al., 1987; Krupa and Crepel, 1989; Rosenmund et al., 1992), which may have been activated by glutamate released from granule neurons that are present in the cerebellar cell preparation (Fig. 1). However, the oscillations were not affected by blocking NMDA receptors either with the competitive inhibitor APV $(50 \mu \mathrm{M} ; n=2)$ or with the open channel blocker MK801 (10 $\mu \mathrm{M} ; n=3$; data not shown). AMPA, $\mathrm{GABA}_{\mathrm{A}}$ and $\mathrm{GABA}_{\mathrm{B}}$ receptors were also not involved in $\mathrm{Ca}^{2+}$ entry because antagonists for these receptors were routinely included in the bath saline (see Materials and Methods).

We then tested inhibitors specific for the three principal classes of VGCCs (P/Q-, N-, and L-types) to determine whether the $\mathrm{Ca}^{2+}$ 

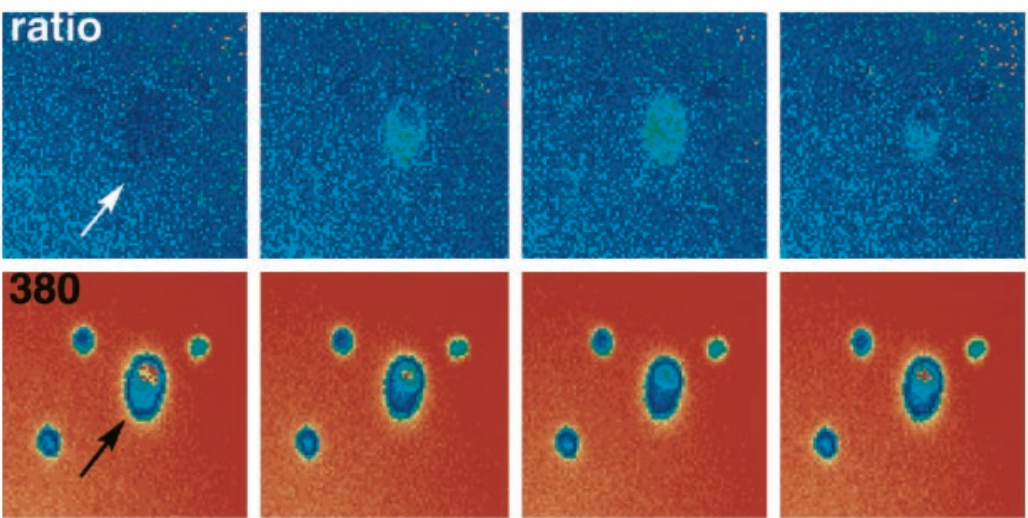

1

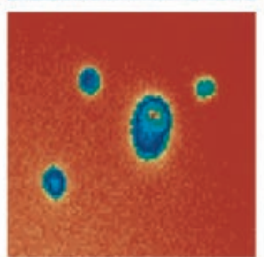

2

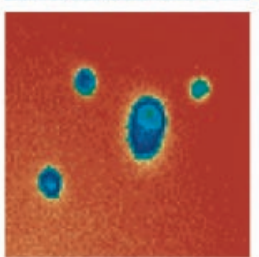

3

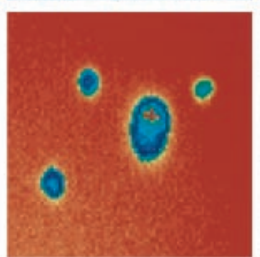

4
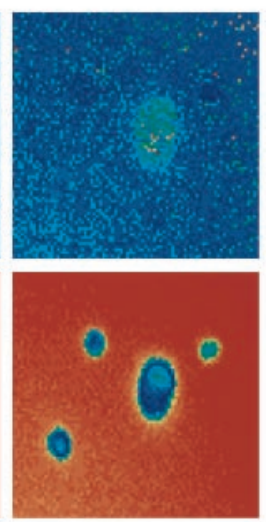

5
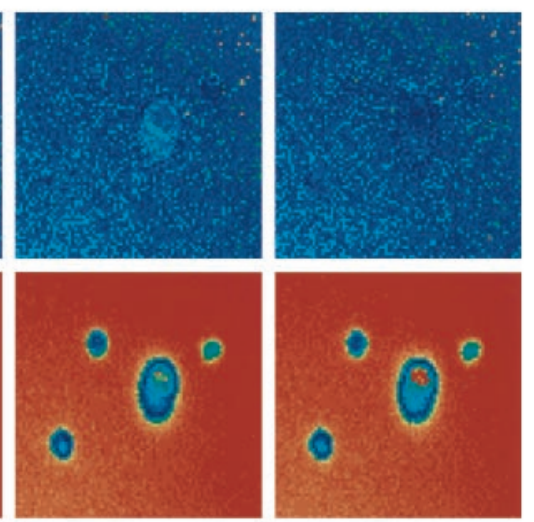

6

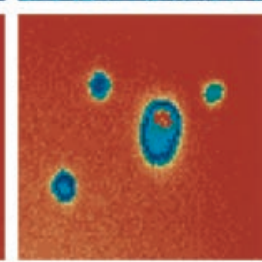

7

B

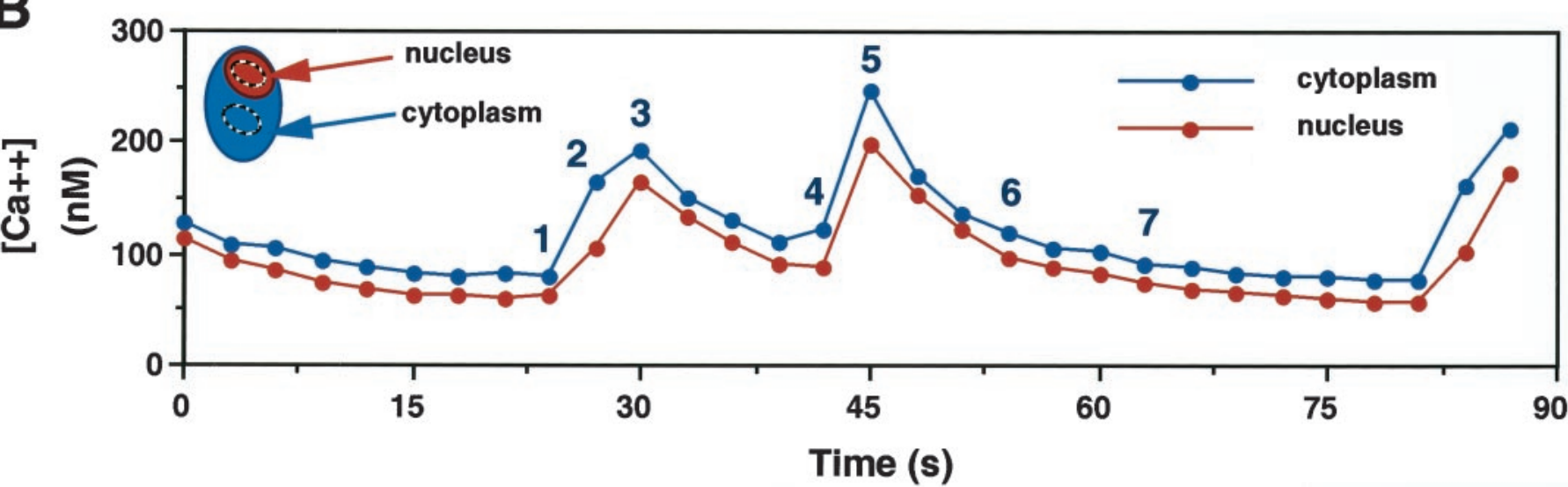

Figure 3. Cytoplasmic $\mathrm{Ca}^{2+}$ oscillations are communicated to the nucleus. $A, \mathrm{Ca}^{2+}$ dynamics in the Purkinje neuron soma. The top row shows digital ratio $(380 / 340 \mathrm{~nm})$ images at selected time points during the $\mathrm{Ca}^{2+}$ recording shown in $B$; a paler blue indicates a higher ratio value. The bottom row shows the corresponding digital $380 \mathrm{~nm}$ wavelength; warmer colors correspond to lower $\mathrm{Ca}^{2+}$ levels, and cooler colors to higher $\mathrm{Ca}^{2+}$ levels. Numbers below the images in $A$ correlate with numbers above collection time points in the $\mathrm{Ca}^{2+}$ trace in $B . B, \mathrm{Ca}^{2+}$ oscillations occurring simultaneously in the cytoplasm and nucleus of a P7 Purkinje neuron. Images were collected at $3 \mathrm{sec}$ intervals for $90 \mathrm{sec}$. The imaging software was used to outline regions of similar size in the nucleus (red; see inset) and cytoplasm (blue) of the digital $\mathrm{Ca}^{2+}$ images.
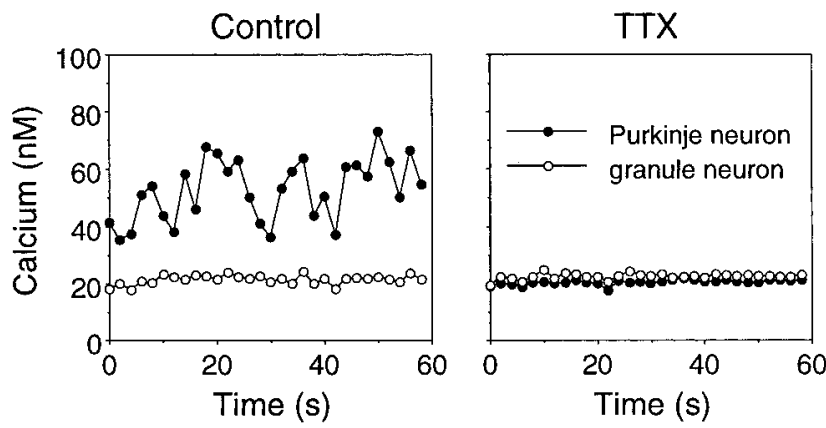

Figure 4. Spontaneous $\mathrm{Ca}^{2+}$ oscillations require $\mathrm{Na}^{+}$channel activity. Representative example of the effect of the $\mathrm{Na}^{+}$channel blocker TTX $(1 \mu \mathrm{M})$ on the spontaneous $\mathrm{Ca}^{2+}$ oscillations of an acutely isolated Purkinje neuron. As shown in this cell, TTX completely blocks the $\mathrm{Ca}^{2+}$ oscillations.

oscillations were dependent on $\mathrm{Ca}^{2+}$ influx through VGCCs. For these studies, measurements were made of the average $\mathrm{Ca}^{2+}$ above baseline and the maximum amplitude of the $\mathrm{Ca}^{2+}$ oscillations under control conditions and after addition of the antagonist to the bath saline. The baseline $\mathrm{Ca}^{2+}$ level for a cell was defined as the lowest $\mathrm{Ca}^{2+}$ level occurring during either the control or antagonist treatment period. Antagonists were considered to be effective if they reduced the average $\mathrm{Ca}^{2+}$ of a cell by $>10 \%$.

Other laboratories have shown that P-type VGCCs are the primary $\mathrm{Ca}^{2+}$ channels mediating $\mathrm{Ca}^{2+}$ influx in 2- to 3-week-old
Purkinje neurons (Regan, 1991; Mintz et al., 1992). However, in our studies on the P4 to P7 Purkinje neurons, the P/Q type VGCC blocker $\omega$-agatoxin IVA $(0.1 \mu \mathrm{M})$ was relatively ineffective (Fig. $6 B$ ), decreasing $\mathrm{Ca}^{2+}$ levels in only 3 of 13 Purkinje neurons. Mean values $\left( \pm\right.$ SEM) for average $\mathrm{Ca}^{2+}$ in the three neurons sensitive to $\omega$-agatoxin IVA were $69 \pm 19 \mathrm{~nm}$ under control conditions and $38 \pm 17 \mathrm{~nm}$ after addition of $\omega$-agatoxin IVA to the recording saline, an $\sim 45 \%$ decrease. Mean values for the maximum amplitude of the $\mathrm{Ca}^{2+}$ oscillations were similar under the two conditions, $169 \pm 32 \mathrm{~nm}$ under control conditions and $161 \pm 36 \mathrm{~nm}$ in the presence of $\omega$-agatoxin IVA $(n=3)$. Similarly, the N-type $\mathrm{Ca}^{2+}$ channel blocker $\omega$-conotoxin GVIA $(1 \mu \mathrm{M})$ decreased $\mathrm{Ca}^{2+}$ levels in only 3 of 8 Purkinje neurons (Fig. $6 C$ ). Mean values for average $\mathrm{Ca}^{2+}$ in the three neurons were $27 \pm 6 \mathrm{nM}$ under control conditions and $18 \pm 3 \mathrm{~nm}$ in the presence of $\omega$-conotoxin GVIA, an $\sim 33 \%$ decrease. Mean values for the maximum amplitude of the $\mathrm{Ca}^{2+}$ oscillations in the three neurons were $102 \pm 16 \mathrm{nM}$ under control conditions and $62 \pm 17 \mathrm{nM}$ in the presence of $\omega$-conotoxin GVIA $(n=3)$, a $39 \%$ decrease.

Surprisingly, the most consistent effects were observed with the L-type VGCC antagonist nimodipine, which was an effective antagonist of the $\mathrm{Ca}^{2+}$ oscillations in 27 of 29 neurons (Fig. $7 A, C$ ). Nimodipine $(1 \mu \mathrm{M})$ reduced both the average $\mathrm{Ca}^{2+}$ and the maximum amplitude of the $\mathrm{Ca}^{2+}$ oscillations in all 27 neurons tested (from 17 preparations between $\mathrm{P} 4$ and $\mathrm{P} 7$ ). In those 27 neurons, mean values for average $\mathrm{Ca}^{2+}$ were $40 \pm 6 \mathrm{nM}$ under control conditions and $16 \pm 4 \mathrm{nM}$ in the presence of nimodipine, a $60 \%$ decrease. Mean values for the maximum amplitude of the $\mathrm{Ca}^{2+}$ 


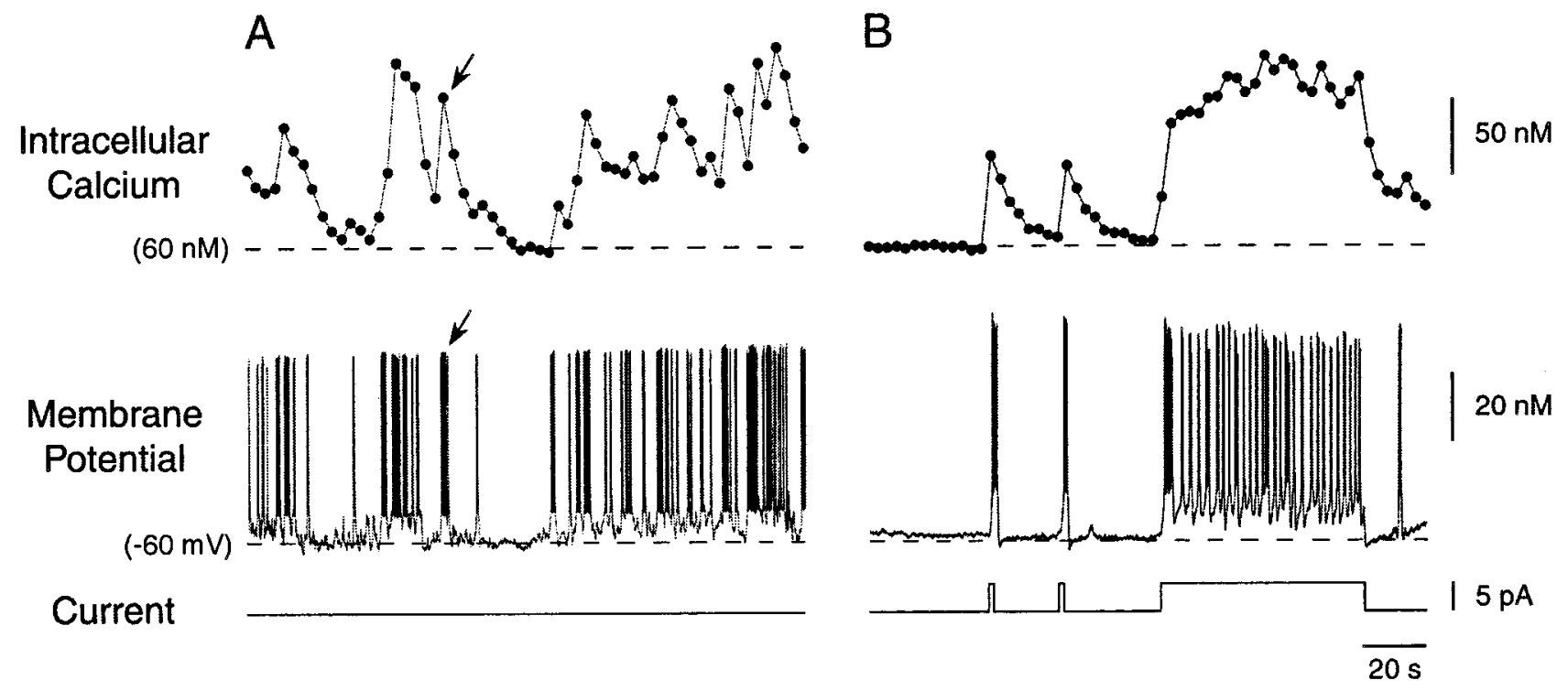

Figure 5. $\mathrm{Ca}^{2+}$ dynamics correlate closely with patterns of electrical activity in immature Purkinje neurons. $A$, Combined recording of the spontaneous $\mathrm{Ca}^{2+}$ oscillations (top trace) and the electrical activity (middle trace) in a single Purkinje neuron recorded at rest (i.e., without applied current; bottom trace). Note that the $\mathrm{Ca}^{2+}$ oscillations correlate with the appearance of spontaneous action potentials. The arrows indicate a burst event in the electrical activity and the corresponding increase of intracellular $\mathrm{Ca}^{2+}$. Electrical activity was recorded under current clamp. $B, \mathrm{Combined} \mathrm{Ca}{ }^{2+}$ imaging/currentclamp recording in another Purkinje neuron. This cell exhibited little change in electrical activity or $\mathrm{Ca}^{2+}$ levels at rest. However, action potentials and corresponding $\mathrm{Ca}^{2+}$ signals could be induced by injecting depolarizing current $(5 \mathrm{pA})$, first in two 2 sec pulses and then in a 50 sec pulse. The elevated resting $\mathrm{Ca}^{2+}$ level during the $50 \mathrm{msec}$ current injection reflects the summation of high-frequency $\mathrm{Ca}^{2+}$ peaks. For both cells, the dashed lines indicate intracellular $\mathrm{Ca}^{2+}$ levels of $60 \mathrm{~nm}$ and a membrane potential of $-60 \mathrm{mV}$.

oscillations were $101 \pm 14 \mathrm{~nm}$ under control conditions and $28 \pm 4$ $\mathrm{nM}$ in the presence of nimodipine $(n=27)$, a $72 \%$ decrease.

When the above data were separated by age, the sensitivity of the $\mathrm{Ca}^{2+}$ oscillations to nimodipine (as measured by the effects of nimodipine on average $\mathrm{Ca}^{2+}$ ) decreased between $\mathrm{P} 4$ and $\mathrm{P} 6$, suggesting a developmental regulation of either the activity or expression of the L-type $\mathrm{Ca}^{2+}$ channel. Mean values for average $\mathrm{Ca}^{2+}$ at $\mathrm{P} 4$ were $36 \pm 7 \mathrm{~nm}(n=9)$ under control conditions and $12 \pm 3 \mathrm{~nm}$ in the presence of nimodipine, a $67 \%$ decrease, whereas at P6 mean values for average $\mathrm{Ca}^{2+}$ were $42 \pm 13 \mathrm{~nm}(n=8)$ under control conditions and $24 \pm 12 \mathrm{~nm}$ in the presence of nimodipine, a $43 \%$ decrease. In combined electrophysiological and $\mathrm{Ca}^{2+}$-imaging experiments, electrical spiking continued in the presence of nimodipine, although $\mathrm{Ca}^{2+}$ oscillations were abolished within seconds of introducing the drug (Fig. $7 C$ ), confirming that although the $\mathrm{Ca}^{2+}$ patterns were directly determined by the electrical activity, the specific influx of $\mathrm{Ca}^{2+}$ mediated by the L-type VGCCs was fundamental and essential to generating the $\mathrm{Ca}^{2+}$ oscillations. Thus, L-type VGCCs appear to be the primary mediators of $\mathrm{Ca}^{2+}$ influx generating the $\mathrm{Ca}^{2+}$ oscillations in the P4 to P7 Purkinje neurons.

Consistent with a dominant role for L-type VGCCs in the generation of the $\mathrm{Ca}^{2+}$ oscillations, the L-type channel-specific agonist BayK-8644 $(1 \mu \mathrm{M})$ enhanced $\mathrm{Ca}^{2+}$ levels in six of eight cells tested (Fig. $7 B, D$ ). For the six cells, mean values for average $\mathrm{Ca}^{2+}$ were $46 \pm 19 \mathrm{~nm}$ under control conditions and $135 \pm 16 \mathrm{nM}$ in the presence of BayK-8644, a $193 \%$ increase. Mean values for the maximum amplitude of the $\mathrm{Ca}^{2+}$ oscillations were $107 \pm 32$ under control conditions and $246 \pm 86 \mathrm{~nm}$ in the presence of BayK-8644 $(n=6)$, a $130 \%$ increase. These results are consistent with the known action of BayK-8644 in prolonging the open time of L-type VGCCs (Hess et al., 1984). In combined electrophysiology/ $\mathrm{Ca}^{2+}$ imaging experiments, addition of BayK-8644 (1 $\left.\mu \mathrm{M}\right)$ to the recording chamber changed the pattern of electrical activity from single-spike to burst events, which correlated with a large sustained increase in the $\mathrm{Ca}^{2+}$ resting level resulting from summation of the $\mathrm{Ca}^{2+}$ oscillations (Fig. $7 D$ ).

\section{Expression of VGCCs in developing Purkinje neurons}

Because our pharmacological results showing a prominent role for L-type VGCCs in the early developing Purkinje neurons were somewhat unexpected, it was important to determine the expression of the L-, P/Q-, and N-type VGCCs at these early developmental stages. Immunostaining of acutely dissociated P5 cerebellar preparations with antibodies against specific subunits of the P-, N-, and L-type VGCCs showed that all three classes of $\mathrm{Ca}^{2+}$ channels were expressed by P5 Purkinje neurons (Fig. 8A). Somatic immunostaining for the P/Q-type channel $\alpha_{1 \mathrm{~A}}$ subunit was strong and uniform for a given neuron, but showed variation from one Purkinje neuron to another. P/Q-type staining extended into the developing apical dendrite when dendritic structure was present (Fig. $8 B)(n=10)$. Immunostaining for L-type $\mathrm{Ca}^{2+}$ channels was uniform over the soma, almost as intense as for the P/Q-type, and heterogeneous in intensity within a given neuronal population. In contrast with the P/Q-type antibody, the L-type antibody did not consistently stain the developing apical dendrite (Fig. $8 B ; n=12$ ), suggesting a predominately somatic role for L-type VGCCs in developing Purkinje neurons. Somatic immunostaining for the N-type VGCCs was much fainter but also uniform for a given neuron. Staining with the N-type antibody was too faint to clearly resolve the presence of dendritic staining.

\section{Amplification of the $\mathrm{Ca}^{2+}$ signal by release of $\mathrm{Ca}^{2+}$ from intracellular $\mathrm{Ca}^{2+}$ stores}

$\mathrm{Ca}^{2+}$ influx through VGCCs is known to be amplified by release of $\mathrm{Ca}^{2+}$ from intracellular stores in Purkinje neurons (Llano et al., 1994; Kano et al., 1995a; Gruol et al., 1996). To test for an involvement of intracellular $\mathrm{Ca}^{2+}$ stores in the $\mathrm{Ca}^{2+}$ oscillations of the immature Purkinje neurons, the neurons were incubated for 20 min in $10 \mu \mathrm{M}$ dantrolene, an agent known to block release of $\mathrm{Ca}^{2+}$ from RyR-gated intracellular $\mathrm{Ca}^{2+}$ stores. Dantrolene decreased the amplitude of the $\mathrm{Ca}^{2+}$ oscillations in 8 of 10 cells (from three preparations; Fig. 9). In those eight neurons, mean values for average $\mathrm{Ca}^{2+}$ were $52 \pm 12 \mathrm{~nm}$ under control conditions and $26 \pm$ $10 \mathrm{~nm}$ in the presence of dantrolene, a $50 \%$ decrease. Mean values for the maximum amplitude of the $\mathrm{Ca}^{2+}$ oscillations were $91 \pm 18$ $\mathrm{nm}$ under control conditions and $39 \pm 13 \mathrm{~nm}$ in the presence of dantrolene $(n=8)$, a $57 \%$ decrease. These results suggested that a large component of the $\mathrm{Ca}^{2+}$ transients originated from intracellular $\mathrm{Ca}^{2+}$ stores. To verify that point, we tested ryanodine, which at relatively high concentrations blocks $\mathrm{Ca}^{2+}$ release from RyR- 

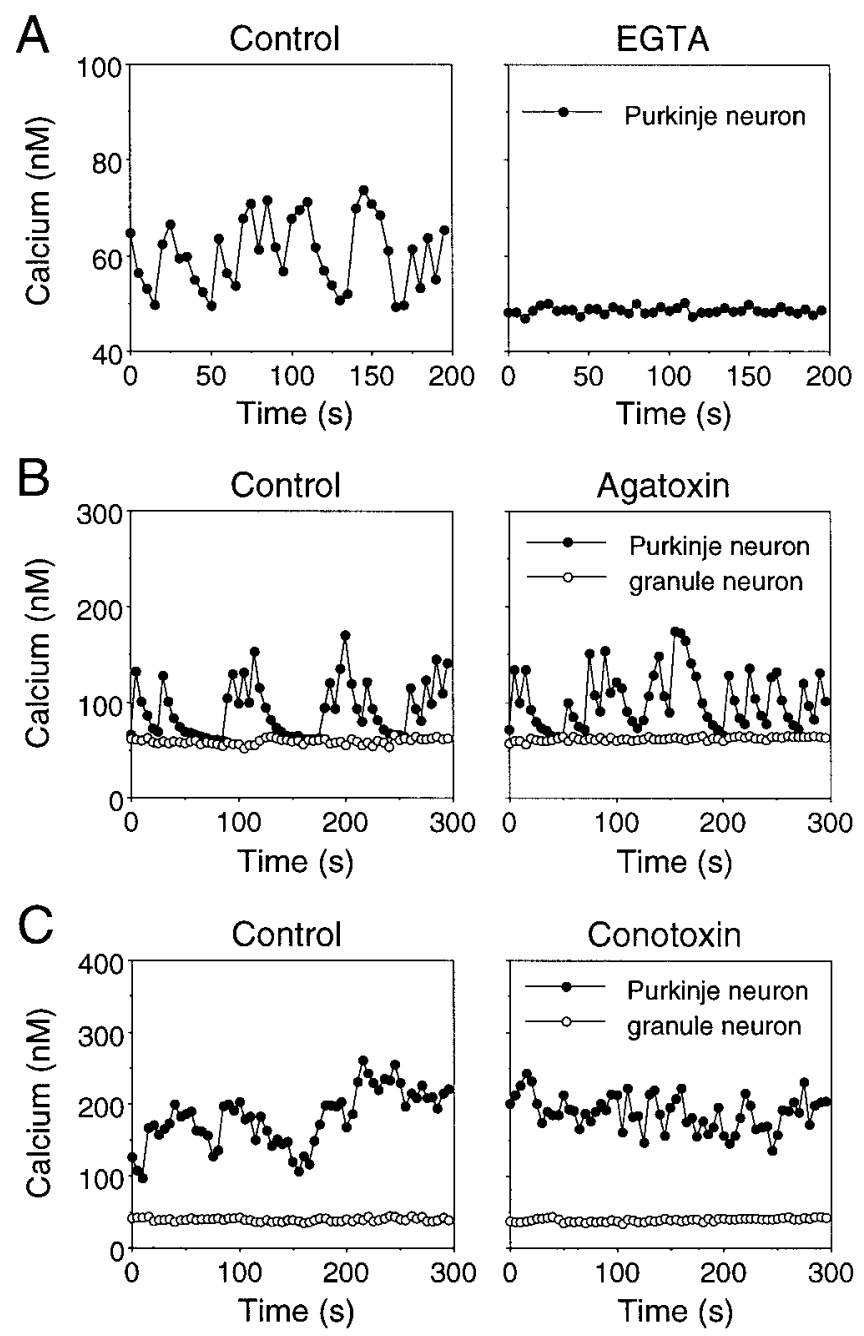

Figure 6. Spontaneous $\mathrm{Ca}^{2+}$ oscillations in developing Purkinje neurons require $\mathrm{Ca}^{2+}$ influx through VGCCs. $A$, The $\mathrm{Ca}^{2+}$ traces show a typical example of the effect of EGTA $(1 \mathrm{mM})$ to block the $\mathrm{Ca}^{2+}$ oscillations in an acutely isolated Purkinje neuron. For these studies, EGTA was applied by bath exchange in physiological saline containing low $\mathrm{Ca}^{2+}(20 \mu \mathrm{M}) . B$, Representative example of the $\mathrm{Ca}^{2+}$ oscillations in a Purkinje neuron before and after bath application of the P/Q-type VGCC antagonist $\omega$-agatoxin IVA $(0.1 \mu \mathrm{M})$. $\omega$-Agatoxin IVA had little effect on the amplitude or frequency of the $\mathrm{Ca}^{2+}$ oscillations. $C, \omega$-Conotoxin GVIA $(1 \mu \mathrm{M})$ was also ineffective at blocking the $\mathrm{Ca}^{2+}$ oscillations as shown in this cell.

gated intracellular $\mathrm{Ca}^{2+}$ stores (Ehrlich et al., 1994). Ryanodine (100 $\mu \mathrm{M} ; 20 \mathrm{~min}$ incubation) depressed the $\mathrm{Ca}^{2+}$ oscillations in 20 of 30 cells (from two preparations). In the 20 cells, mean values for average $\mathrm{Ca}^{2+}$ were $28 \pm 4 \mathrm{nM}$ under control conditions and $10 \pm$ $2 \mathrm{~nm}$ in the presence of ryanodine, a $64 \%$ decrease. Mean values for the maximum amplitude of the $\mathrm{Ca}^{2+}$ oscillations were $68 \pm 9 \mathrm{nM}$ under control conditions and $30 \pm 9 \mathrm{~nm}$ in the presence of ryanodine $(n=20)$, a $56 \%$ decrease.

\section{DISCUSSION}

Results from the current study show that spontaneous oscillations in intracellular $\mathrm{Ca}^{2+}$ are a prominent feature of early developing Purkinje neurons and that the $\mathrm{Ca}^{2+}$ oscillations are elicited by endogenously generated electrical activity that is expressed by this neuronal type (Woodward et al., 1969a,b; Crepel, 1972; Gruol and Franklin, 1987; Gruol et al., 1991; Nam and Hockberger, 1997; Raman and Bean, 1997, 1999). The $\mathrm{Ca}^{2+}$ oscillations are initiated by influx of $\mathrm{Ca}^{2+}$ through L-type VGCCs, which is then amplified by release of $\mathrm{Ca}^{2+}$ from RyR-gated intracellular $\mathrm{Ca}^{2+}$ stores and transmitted to the nucleus, a result that may have implications for gene regulation during neuronal development. These observations made with early developing Purkinje neurons contrast with the known predominant role of P-type VGCCs in $\mathrm{Ca}^{2+}$ signaling in the dendritic region of mature Purkinje neurons (Hillman et al., 1991; Usowicz et al., 1992).

$\mathrm{Ca}^{2+}$ oscillations have been reported to occur spontaneously in several neuronal types (Sorimachi et al., 1990; Yuste et al., 1992; Gu et al., 1994; Gomez et al., 1995; Gu and Spitzer, 1995; Wong et al., 1995; Komuro and Rakic, 1996; Owens and Kriegstein, 1998; Gomez and Spitzer, 1999), and in some cases have been shown to play a role in the developmental process. For example, developmental signals for neurotransmitter expression and growth cone migration in embryonic Xenopus spinal neurons are encoded in patterns of spontaneous intracellular $\mathrm{Ca}^{2+}$ transients ( $\mathrm{Gu}$ et al., 1994; Gu and Spitzer, 1995; Gomez and Spitzer, 1999). Spontaneous $\mathrm{Ca}^{2+}$ oscillations also play a critical role in regulating the advancement of the leading process of migrating cerebellar granule neurons (Komuro and Rakic, 1996), as well as, of chick retinal ganglion cell growth cones (Gomez et al., 1995). In these neuronal types, the trigger for spontaneous $\mathrm{Ca}^{2+}$ oscillations is still under investigation. However, our combined $\mathrm{Ca}^{2+}$ imaging and electrophysiological recordings show that the $\mathrm{Ca}^{2+}$ oscillations observed in the early developing Purkinje neurons are generated by spontaneous electrical activity that is endogenously generated.

The ability of immature Purkinje neurons to endogenously generate electrical activity both in the immature and mature states has been documented for Purkinje neurons in acutely isolated cerebellar cell preparations (Nam and Hockberger 1997; Raman and Bean, 1997, 1999), in cerebellar culture preparations (Gruol and Franklin, 1987; Gruol et al., 1991), and in vivo as early as 2 d postnatal (Woodward et al., 1969a,b; Crepel, 1972). Ionic models involving "resurgent" sodium currents (Raman and Bean, 1997) or sodium "window currents" (Nam and Hockberger, 1997) have been proposed to account for this component of the electrical activity of Purkinje neurons. Synaptic input also contributes to the spontaneous activity of mature and developing Purkinje neurons in vivo and in culture and may play a role in the $\mathrm{Ca}^{2+}$ dynamics of early developing Purkinje neurons. However, this component could not be examined in the current study because the synaptic connections were removed during the isolation procedure.

Our results show that the patterns of spontaneous electrical activity and $\mathrm{Ca}^{2+}$ oscillations are tightly linked in the early developing Purkinje neurons and that clusters of action potentials produce peaks of $\mathrm{Ca}^{2+}$. Moreover, a higher frequency of action potentials corresponds to a $\mathrm{Ca}^{2+}$ response of greater amplitude. Thus, the level of electrical activity of early developing Purkinje plays a critical role in defining the level of intracellular $\mathrm{Ca}^{2+}$. Different patterns of spontaneous electrical activity were present within a population of the acutely isolated Purkinje neurons at a single age, presumably resulting from ongoing developmental processes. The pattern of spontaneous electrical activity in Purkinje neurons is known to change with the developmental program (Woodward et al., 1969a,b; Gruol and Franklin, 1987). Therefore, it is likely that the patterns of $\mathrm{Ca}^{2+}$ oscillations produced by the spontaneous electrical activity will also change during development.

Pharmacological analysis showed that the $\mathrm{Ca}^{2+}$ oscillations in the developing Purkinje neurons are generated by the entry of extracellular $\mathrm{Ca}^{2+}$ through L-type VGCCs. This was unexpected because the P-type channel blockers $\omega$-agatoxin IVA and funnel web spider toxin almost completely inhibit $\mathrm{Ca}^{2+}$ currents in acutely isolated Purkinje neurons from 2- to 3-week-old rats (Mintz et al., 1992) and in the dendrites of mature Purkinje neurons (Usowicz et al., 1992), respectively, indicating the functional importance of P/Q-type VGCCs at these stages. The dihydropyridine agonist BayK-8644 did not enhance $\mathrm{Ca}^{2+}$ influx in mature Purkinje neurons (Usowicz et al., 1992), implying that L-type $\mathrm{Ca}^{2+}$ channels do not play a prominent functional role in the mature dendritic arbor. However, the $\mathrm{N}$-type $\mathrm{Ca}^{2+}$ channel blocker $\omega$-conotoxin GVIA inhibited $6 \%$, and the L-type $\mathrm{Ca}^{2+}$ channel blocker nitrendipine inhibited $8 \%$ of the high-threshold $\mathrm{Ca}^{2+}$ currents in acutely isolated Purkinje neurons from 1- to 3-week-old rats (Regan, 1991), 


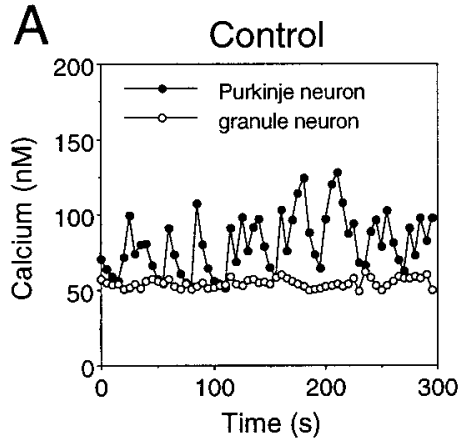

C
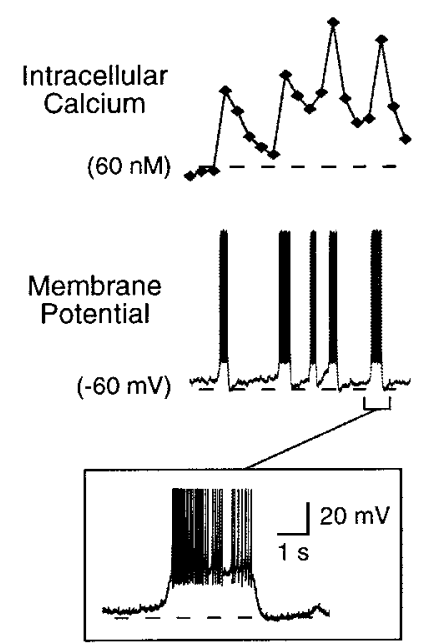

Nimodipine

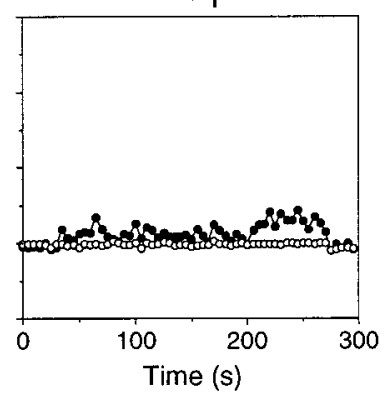

Nimodipine
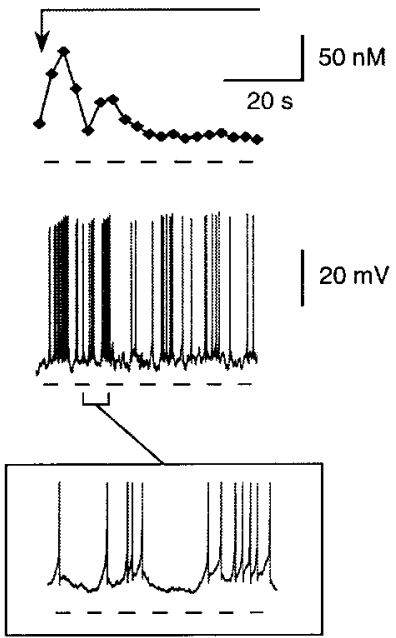
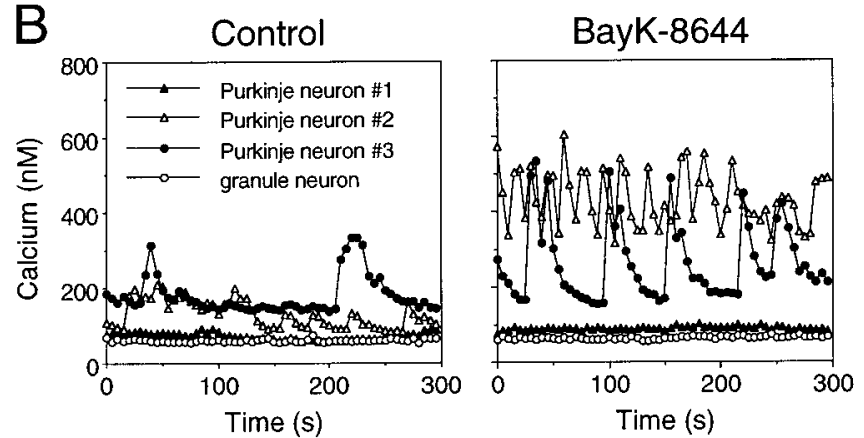

D

Control
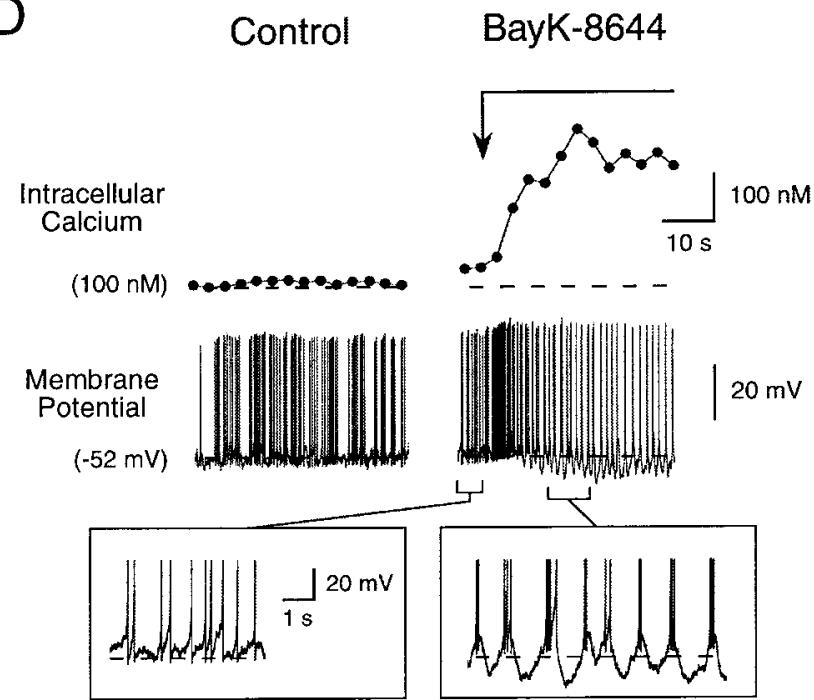

Figure 7. L-type VGCCs mediate $\mathrm{Ca}^{2+}$ influx that generates intracellular $\mathrm{Ca}^{2+}$ oscillations in immature Purkinje neurons. $A$, Representative example of the effect of nimodipine $\left(1 \mu \mathrm{M}\right.$; added to the bath saline) to nearly block $\mathrm{Ca}^{2+}$ oscillations in an acutely isolated Purkinje neuron. $B$, Incubation of the cells with BayK-8644 $(1 \mu \mathrm{M})$ dramatically enhanced the $\mathrm{Ca}^{2+}$ oscillations of oscillating Purkinje neurons. $C$, Combined $\mathrm{Ca}{ }^{2+}$-imaging, current-clamp experiment showing simultaneous inhibition of spontaneous $\mathrm{Ca}^{2+}$ oscillations and spontaneous electrical activity by nimodipine $(1 \mu \mathrm{M})$. Nimodipine was applied to the bath saline at the arrow and was present throughout the remainder of the recording period. $D$, Combined Ca ${ }^{2+}$ imaging, current-clamp experiment showing the simultaneous effect of BayK-8644 $(1 \mu \mathrm{M})$ on spontaneous $\mathrm{Ca}^{2+}$ oscillations and spontaneous electrical activity. BayK-8644 was applied to the bath saline at the arrow and was present throughout the remainder of the recording period. Recordings in $C$ and $D$ are at the resting membrane potential of the cells; dashed lines denote $\mathrm{Ca}^{2+}$ levels and membrane potential as indicated to the left of the lines. Insets in $C$ and $D$ show records of the spike activity at an expanded time scale.

indicating that both of these channel types contributed to $\mathrm{Ca}^{2+}$ influx in developing Purkinje neurons. In our experiments, spontaneous $\mathrm{Ca}^{2+}$ oscillations in P4 to P7 Purkinje neurons were strongly inhibited by nimodipine as well as enhanced by the dihydropyridine agonist BayK-8644. Together, these results indicate that functional L-type VGCCs are present on Purkinje cells at an early age, and that these $\mathrm{Ca}^{2+}$ channels play an important role in $\mathrm{Ca}^{2+}$ signaling in early development.

Intracellular $\mathrm{Ca}^{2+}$ stores in the endoplasmic reticulum represent a critical intermediary step in many neuronal $\mathrm{Ca}^{2+}$ signaling pathways. Our results show that early in development, a somatic $\mathrm{Ca}^{2+}$ signaling pathway links $\mathrm{Ca}^{2+}$ entering through L-type VGCCs to $\mathrm{Ca}^{2+}$-mediated release of $\mathrm{Ca}^{2+}$ from the RyR-gated intracellular $\mathrm{Ca}^{2+}$ stores. A similar $\mathrm{Ca}^{2+}$ signaling pathway has been shown to generate spontaneous $\mathrm{Ca}^{2+}$ oscillations in the rat frontal cortex (Hayashi et al., 1997) and agonist-evoked $\mathrm{Ca}^{2+}$ signals in other neuronal types (Chavis et al., 1996; Ronde and Nichols, 1997). IP3R-gated intracellular $\mathrm{Ca}^{2+}$ stores could also contribute to the spontaneous $\mathrm{Ca}^{2+}$ signals observed in the current study, if ambient IP3 and $\mathrm{Ca}^{2+}$ levels were sufficient to activate this pathway. IP3mediated release of $\mathrm{Ca}^{2+}$ from the IP3R-gated intracellular $\mathrm{Ca}^{2+}$ stores has been shown to be important in dendritic $\mathrm{Ca}^{2+}$ signaling in Purkinje neurons (Gruol et al., 1996; Netzeband et al., 1997; Finch and Augustine, 1998) in addition to $\mathrm{Ca}^{2+}$ release linked to
RyRs (Llano et al., 1994; Gruol et al., 1996). Future studies will address this issue.

Immunostaining by other laboratories has shown that all three types of high-threshold VGCCs (P/Q-, L-, N-) are present on mature Purkinje neurons (Ahlijanian et al., 1990; Hillman et al., 1991; Westenbroek et al., 1992). Our results show that all three VGCC types are already expressed in the soma of immature Purkinje neurons by the first postnatal week. However, pharmacological analysis showed that $\mathrm{P}$ - and $\mathrm{N}$-type $\mathrm{Ca}^{2+}$ channels do not play a prominent role in generating the $\mathrm{Ca}^{2+}$ oscillations and that L-type VGCCs were the predominant $\mathrm{Ca}^{2+}$ channel involved. This selective involvement of L-type VGCCs in the $\mathrm{Ca}^{2+}$ oscillations could reflect functional coupling between L-type VGCCs and RyR-gated intracellular $\mathrm{Ca}^{2+}$ stores, as has been shown to exist in other neuronal systems (Chavis et al., 1996). Such an association produces selective amplification of $\mathrm{Ca}^{2+}$ signals through L-type VGCCs. Alternatively, other features of the $\mathrm{Ca}^{2+}$ signaling system such as the topographic distribution of VGCCs or intracellular $\mathrm{Ca}^{2+}$ stores may underlie the prominent role of L-type VGCCs. Further studies will be necessary to resolve this issue.

Activation of L-type $\mathrm{Ca}^{2+}$ channels has been directly linked to second messenger pathways that lead to increased expression of immediate early genes in several neuronal cell types (Murphy et al., 1991; Bading et al., 1993; Deisseroth et al., 1998; Rajadhyaksha et 


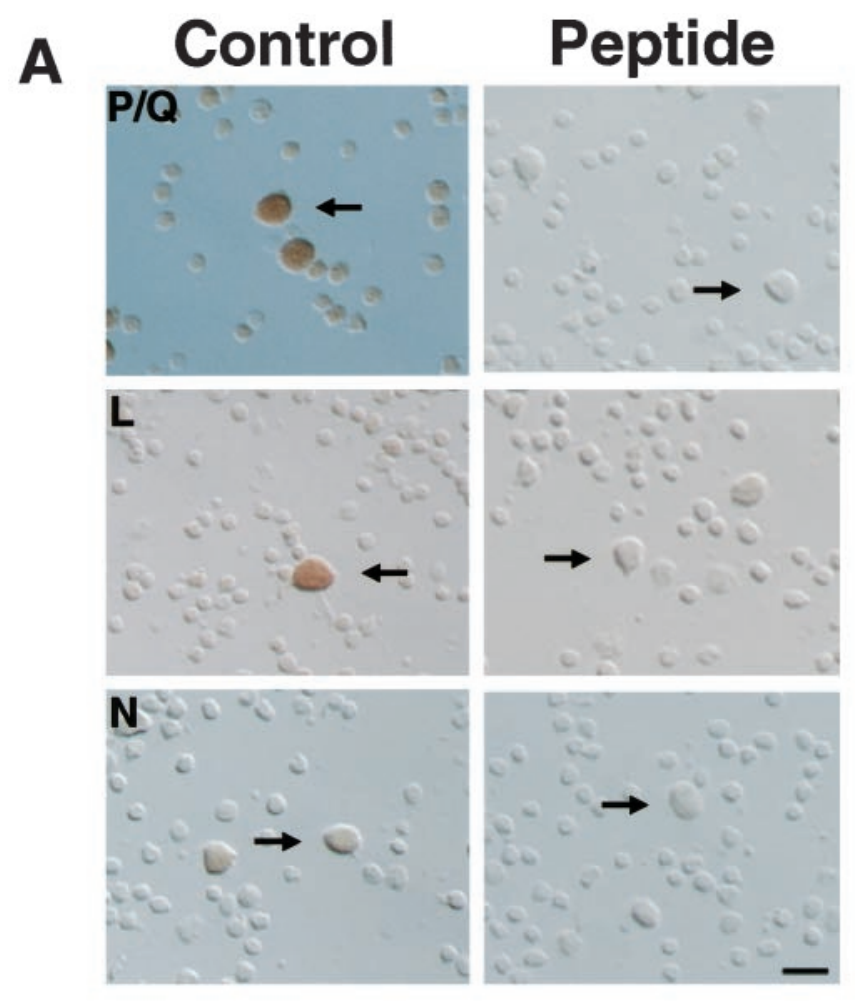

B

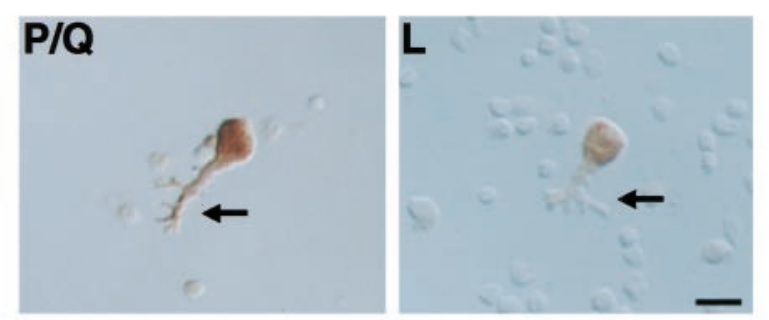

Figure 8. P/Q-, N-, and L-type VGCCs are expressed by immature Purkinje neurons. $A$, Photomicrographs showing immunoreactivity of early developing Purkinje neurons (arrows) for $\mathrm{P} / \mathrm{Q}-($ top, left panel), L- (middle, left panel), and N-type (bottom, left panel) VGCCs. P/Q-, L-, and N-type VGCCs were immunostained with antibodies to the $\alpha_{1 \mathrm{~A}}, \alpha_{1 \mathrm{C}}$, and $\alpha_{1 \mathrm{~B}}$ subunits of $\mathrm{Ca}^{2+}$ channels, respectively. Immunoreactivity is indicated by the brown color and was blocked in the presence of the corresponding blocking peptide (1:1 ratio of the antibody and peptide by weight) as shown in the panels to the right. All panels show P5 neurons. B, Photomicrographs demonstrating the relative expression of $\mathrm{P} / \mathrm{Q}$-type (left panel) and L-type (right panel) VSCCs in the developing apical dendrites (arrows) compared with the somata of immature Purkinje neurons. The dendrites typically expressed P-type VGCCs with relatively low levels of immunoreactivity for L-type VGCCs. Both panels show P7 neurons. Scale bars, $15 \mu \mathrm{m}$.

al., 1999). Our studies showing that electrically induced $\mathrm{Ca}^{2+}$ oscillations are transmitted to the nucleus suggest that such a pathway may be important for signaling in developing Purkinje neurons. Studies in other cell types have shown that cytosolic $\mathrm{Ca}^{2+}$ signals can be translated into changes in nuclear $\mathrm{Ca}^{2+}$ and that nuclear $\mathrm{Ca}^{2+}$ signals can also be initiated in the nucleus (Kocsis et al., 1994; Gerasimenko et al., 1996). Both RyRs and IP3Rs are present on the nuclear membrane (Kocsis et al., 1994; Gerasimenko et al., 1996; Humbert et al., 1996), a membrane that is formed by an extension of the endoplasmic reticulum. Nuclear $\mathrm{Ca}^{2+}$ has been shown to be capable of modulating transcription (Hardingham et al., 1997) and dynamic changes in the nuclear $\mathrm{Ca}^{2+}$ pool, including $\mathrm{Ca}^{2+}$ oscillations and bursts of $\mathrm{Ca}^{2+}$ transients have been shown to act as specific switches for increasing gene expression (Gu and Spitzer, 1995; Dolmetsch et al., 1998; Li et al., 1998), potentially by activating $\mathrm{Ca}^{2+}$-sensitive intermediary
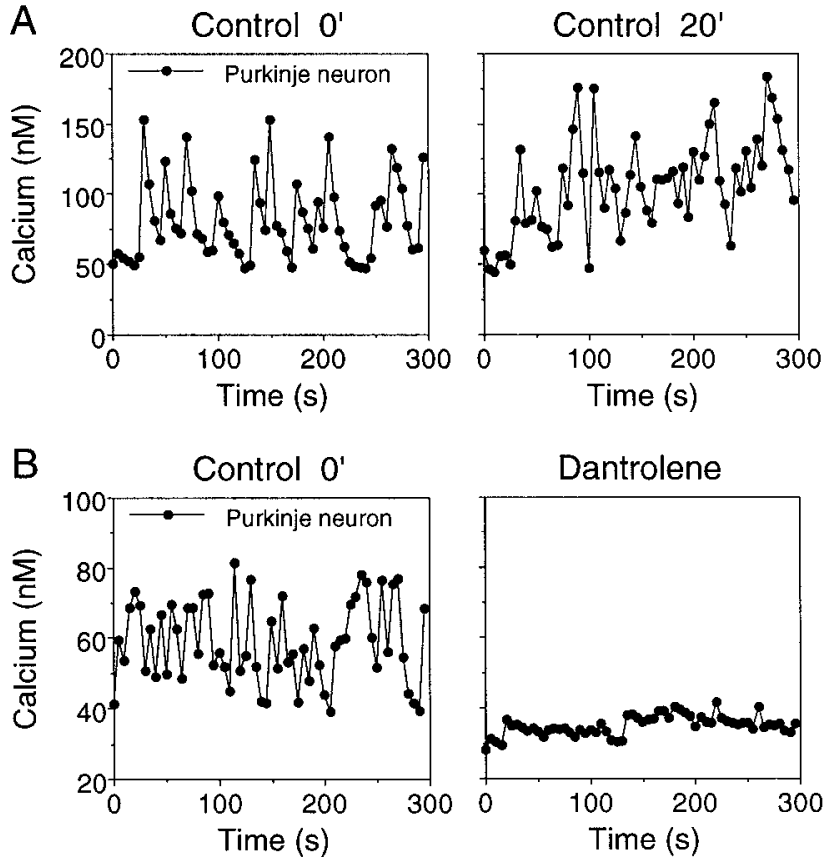

C

Control

Dantrolene

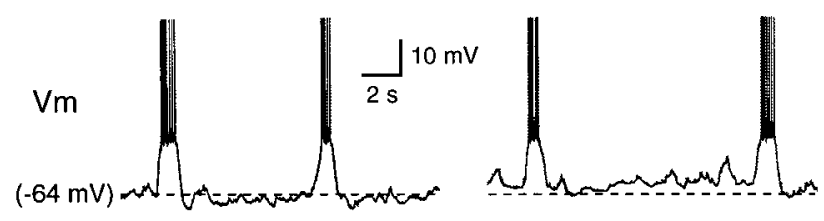

Figure 9. $\mathrm{Ca}^{2+}$ signals of extracellular origin are amplified by release of $\mathrm{Ca}^{2+}$ from intracellular $\mathrm{Ca}^{2+}$ stores. $A$, Representative examples of the $\mathrm{Ca}^{2+}$ oscillations observed in an immature Purkinje neuron at time $0\left(0^{\prime}\right)$ and $20 \mathrm{~min}\left(20^{\prime}\right)$ later. Under control conditions there was little change in the amplitude or frequency of the $\mathrm{Ca}^{2+}$ oscillations over time. $B$, Typical $\mathrm{Ca}^{2+}$ traces showing the effect of the RyR antagonist dantrolene $(10 \mu \mathrm{M} ; 20$ min incubation) to depress $\mathrm{Ca}^{2+}$ oscillations in an another Purkinje neuron. $C$, Current-clamp recording of the spontaneous electrical activity in another Purkinje neuron showing the persistence of electrical spiking after the 20 min incubation with dantrolene $(10 \mu \mathrm{M})$. Resting membrane potential $(-64 \mathrm{mV})$ is indicated by the dashed line. $V m$, Membrane voltage.

components such as the enzyme CaM kinase II (DeKoninck and Schulman, 1998) or the transcription factor cAMP response element-binding protein (Hardingham et al., 1997). Thus, $\mathrm{Ca}^{2+}$ oscillations generated by the coordinated action of spontaneous electrical activity, L-type voltage-sensitive $\mathrm{Ca}^{2+}$ channels, and RyR-gated intracellular $\mathrm{Ca}^{2+}$ stores may represent a developmental signal linking electrical activity at the neuronal cell membrane with changes in gene expression in developing Purkinje neurons.

\section{REFERENCES}

Ahlijanian MK, Westenbroek RE, Catterall WA (1990) Subunit structure and localization of dihydropyridine-sensitive $\mathrm{Ca}^{2+}$ channels in mammalian brain, spinal cord, and retina. Neuron 4:819-832.

Altman J (1972) Postnatal development of the cerebellar cortex in the rat. II. Phases in the maturation of Purkinje cells and of the molecular layer. J Comp Neurol 145:399-464.

Altman J, Bayer SA (1997) Development of the cerebellar system in relation to its evolution, structure and functions. New York: CRC.

Bading H, Ginty DD, Greenberg ME (1993) Regulation of gene expression in hippocampal neurons by distinct calcium signaling pathways. Science 260:181-186.

Baptista CA, Hatten ME, Blazeski R, Mason CA (1994) Cell-cell interactions influence survival and differentiation of purified Purkinje cells in vitro. Neuron 12:243-260.

Chavis P, Fagni L, Lansman JB, Bockaert J (1996) Functional coupling between ryanodine receptors and L-type calcium channels in neurons. Nature 382:719-722.

Crepel F (1972) Maturation of the cerebellar Purkinje cells. I. Postnatal 
evolution of the Purkinje cell spontaneous firing in the rat. Exp Brain Res 14:463-472.

Deisseroth K, Heist EK, Tsien RW (1998) Translocation of calmodulin to the nucleus supports CREB phosphorylation in hippocampal neurons. Nature 392:198-202.

De Koninck P, Schulman H (1998) Sensitivity of CaM kinase II to the frequency of $\mathrm{Ca}^{2+}$ oscillations. Science 279:227-230.

Dolmetsch RE, Xu K, Lewis RS (1998) Calcium oscillations increase the efficiency and specificity of gene expression. Nature 392:933-936.

Ehrlich BE, Kaftan E, Bezprozvannaya S, Bezprozvanny I (1994) The pharmacology of intracellular $\mathrm{Ca}^{2+}$-release channels. Trends Pharmacol Sci 15:145-149.

Eilers J, Augustine GJ, Konnerth A (1995) Subthreshold synaptic Ca ${ }^{2+}$ signaling in fine dendrites and spines of cerebellar Purkinje neurons. Nature 373:155-158.

Eilers J, Plant T, Konnerth A (1996) Localized calcium signaling and neuronal integration in cerebellar Purkinje neurons. Cell Calcium 20:215-226.

Enderlin S, Norman AW, Celio MR (1987) Ontogeny of the calcium binding protein calbindinD-28k in the rat nervous system. Anat Embryol 177:15-28.

Finch EA, Augustine GJ (1998) Local calcium signalling by inositol-1,4,5trisphosphate in Purkinje cell dendrites. Nature 396:753-760.

Garthwaite G, Yamini Jr B, Garthwaite J (1987) Selective loss of Purkinje and granule cell responsiveness to $N$-methyl-D-aspartate in rat cerebellum during development. Dev Brain Res 36:288-292.

Gerasimenko OV, Gerasimenko JV, Tepikin AV, Peterson OH (1996) Calcium transport pathways in the nucleus. Pflügers Arch 432:1-6.

Gomez TM, Spitzer NC (1999) In vivo regulation of axon extension and pathfinding by growth-cone calcium transients. Nature 397:350-354.

Gomez T, Snow DW, Letourneau PC (1995) Characterization of spontaneous calcium transients in nerve growth cones and their effect on growth cone migration. Neuron 14:1233-1246.

Gruol DL, Franklin CL (1987) Morphological and physiological differentiation of Purkinje neurons in cultures of rat cerebellum. J Neurosc 7:1271-1293.

Gruol DL, Jacquin T, Yool AJ (1991) Single-channel K ${ }^{+}$currents recorded from the somatic and dendritic regions of cerebellar Purkinje neurons in culture. J Neurosci 11:1002-1015.

Gruol DL, Deal CR, Yool AJ (1992) Developmental changes in calcium conductances contribute to the physiological maturation of cerebellar Purkinje neurons in culture. J Neurosci 12:2838-2848.

Gruol DL, Netzeband JG, Parsons KL (1996) $\mathrm{Ca}^{2+}$ signaling pathways linked to glutamate receptor activation in the somatic and dendritic regions of cultured cerebellar Purkinje neurons. J Neurophysiol 76:3325-3340.

Gu X, Spitzer NC (1995) Distinct aspects of neuronal differentiation encoded by frequency of spontaneous $\mathrm{Ca}^{2+}$ transients. Nature 375:784-787. Gu X, Olson EC, Spitzer NC (1994) Spontaneous neuronal calcium spikes and waves during early differentiation. J Neurosci 14:6325-6335.

Hardingham GE, Chawla S, Johnson CM, Bading H (1997) Distinct functions of nuclear and cytoplasmic calcium in the control of gene expression. Nature 260-265.

Hayashi T, Kagaya A, Takebayashi M, Oyamada T, Inagaki M, Tawara Y, Yokota N, Horiguchi J, Su T-P, Yamawaki S (1997) Effect of dantrolene on KCl- or NMDA-induced intracellular $\mathrm{Ca}^{2+}$ changes and spontaneous $\mathrm{Ca}^{2+}$ oscillation in cultured rat frontal cortical neurons. J Neural Transm 104:811-824.

Hess P, Lansman JB, Tsien RW (1984) Different modes of $\mathrm{Ca}^{2+}$ gating behavior favored by dihydropyridine $\mathrm{Ca}^{2+}$ agonists and antagonists. Nature 311:538-544.

Hillman D, Chen S, Aung TT, Cherksey B, Sugimori M, Llinas R (1991) Localization of P-type calcium channels in the central nervous system. Proc Natl Acad Sci USA 88:7076-7080.

Hockberger PE, Tseng H-Y, Connor JA (1989) Fura-2 measurements of cultured rat Purkinje neurons show dendritic localization of $\mathrm{Ca}^{2+}$ influx. J Neurosci 9:2272-2284.

Hockberger PE, Yousif L, Nam JSC (1994) Identification of acutely isolated cells from developing rat cerebellum. NeuroImage 1:276-287.

Humbert J-P, Matter N, Artault J-C, Koppler P, Malviya AN (1996) Inositol 1,4,5-trisphosphate receptor is located to the inner nuclear membrane vindicating regulation of nuclear calcium signaling by inositol 1,4,5-trisphosphate. Discrete distribution of inositol phosphate receptors to inner and outer nuclear membranes. J Biol Chem 271:478-485.

Kano M, Garaschuk O, Verkhratsky A, Konnerth A (1995a) Ryanodine receptor-mediated intracellular calcium release in rat cerebellar Purkinje neurons. J Physiol (Lond) 487:1-16.

Kano M, Schneggenburger R, Verkhratsky A, Konnerth A (1995b) Depolarization-induced calcium signals in the somata of cerebellar Purkinje neurons. Neurosci Res 24:87-95.

Kocsis JD, Rand MN, Lankford KL, Waxman SG (1994) Intercellular calcium mobilization and neurite outgrowth in mammalian neurons. J Neurobiol 25:252-264.

Komuro H, Rakic P (1996) Intracellular $\mathrm{Ca}^{2+}$ fluctuations modulate the rate of neuronal migration. Neuron 17:275-285.

Konnerth A, Dreessen J, Augustine GJ (1992) Brief dendritic calcium signals initiate long-lasting synaptic depression in cerebellar Purkinje cells. Proc Natl Acad Sci USA 89:7051-7055.
Krupa M, Crepel F (1989) Transient sensitivity of rat cerebellar Purkinje cells to $N$-methyl-D-aspartate during development. A voltage clamp study in in vitro slices. Eur J Neurosci 2:312-316.

Li W-H, Llopis J, Whitney M, Zlokarnik G, Tsien RY (1998) Cellpermeant caged $\mathrm{Ins}_{3}$ ester shows that $\mathrm{Ca}^{2+}$ spike frequency can optimize gene expression. Nature 392:936-941.

Llano I, DiPolo R, Marty A (1994) Calcium-induced calcium release in cerebellar Purkinje cells. Neuron 12:663-673.

Mason CA, Christakos S, Catalano SM (1990) Early climbing fiber interactions with Purkinje cells in the postnatal mouse cerebellum. J Comp Neurol 297:77-90.

Milosevic A, Zecevic N (1998) Developmental changes in human cerebellum: expression of intracellular calcium receptors, calcium-binding proteins, and phosphorylated and nonphosphorylated neurofilament protein. J Comp Neurol 396:442-460.

Mintz IM, Venema VJ, Swiderek K, Lee T, Bean BP, Adams ME (1992) P-type calcium channels blocked by the spider toxin $\omega$-Aga-IVA. Nature 355:827-829.

Miyakawa H, Lev-Ram V, Lasser-Ross N, Ross WN (1992) Calcium transients evoked by climbing fiber and parallel fiber synaptic inputs in guinea pig cerebellar Purkinje neurons. J Neurophysiol 68:1178-1189.

Murphy TH, Worley PF, Baraban JM (1991) L-type voltage-sensitive calcium channels mediate synaptic activation of immediate early genes. Neuron 7:625-635.

Nam SC, Hockberger PE (1997) Analysis of spontaneous electrical activity in cerebellar Purkinje cells acutely isolated from postnatal rats. J Neurobiol 33:18-32.

Narasimhan K, Pessah IN, Linden DJ (1998) Inositol-1,4,5-trisphosphate receptor-mediated $\mathrm{Ca}$ mobilization is not required for cerebellar longterm depression in reduced preparations. J Neurophysiol 80:2963-2974.

Netzeband JG, Parsons KL, Sweeney DD, Gruol DL (1997) Metabotropic glutamate receptor agonists alter neuronal excitability and $\mathrm{Ca}^{2+}$ levels via the phospholipase $\mathrm{C}$ transduction pathway in cultured Purkinje neurons. J Neurophysiol 78:63-75.

Owens DF, Kriegstein AR (1998) Patterns of intracellular calcium fluctuation in precursor cells of the neocortical ventricular zone. J Neurosci 18:5374-5388.

Rajadhyaksha A, Barczak A, Macias W, Leveque J-C, Lewis SE, Konradi C (1999) L-type $\mathrm{Ca}^{2+}$ channels are essential for glutamate-mediated CREB phosphorylation and c-fos gene expression in striatal neurons. J Neurosci 19:6348-6359.

Raman IM, Bean BP (1997) Resurgent sodium current and action potential formation in dissociated cerebellar Purkinje neurons. J Neurosci 17:4517-4526.

Raman IM, Bean BP (1999) Ionic currents underlying spontaneous action potentials in isolated cerebellar Purkinje neurons. J Neurosci 19:1663-1674.

Regan LJ (1991) Voltage-dependent calcium currents in Purkinje cells from rat cerebellar vermis. J Neurosci 11:2259-2269.

Ronde P, Nichols RA (1997) $5-\mathrm{HT}_{3}$ receptors induce rises in cytosolic and nuclear calcium in NG108-15 cells via calcium-induced calcium release. Cell Calcium 22:357-365.

Rosenmund C, Legendre P, Westbrook GL (1992) Expression of NMDA channels on cerebellar Purkinje cells acutely dissociated from newborn rats. J Neurophysiol 68:1901-1905.

Ross WN, Werman R (1987) Mapping calcium transients in the dendrites of Purkinje cells from the guinea pig cerebellum in vitro. J Physiol (Lond) 389:319-336.

Sorimachi M, Morita Y, Nakamura H (1990) Possible regulation of the cytosolic-free calcium concentration by $\mathrm{Na}^{+}$spikes in immature cerebellar Purkinje cells. Neurosci Lett 111:333-338.

Sugimori M, Llinas RR (1990) Real-time imaging of calcium influx in mammalian cerebellar Purkinje cells in vitro. Proc Natl Acad Sci USA 87:5084-5088

Surmeier DJ, Stefani A, Foehring R, Kitai ST (1991) Developmental expression of a slowly-inactivating voltage-dependent potassium current in rat neostriatal neurons. Neurosci Lett 122:41-46.

Tank DW, Sugimori M, Connor JA, Llinas RR (1988) Spatially resolved calcium dynamics of mammalian Purkinje cells in cerebellar slice. Science 242:773-777.

Usowicz MM, Sugimori M, Cherksey B, Llinas R (1992) P-type calcium channels in the somata and dendrites of adult cerebellar Purkinje cells. Neuron 9:1185-1199.

Westenbroek RE, Hell JW, Warner C, Dubel SJ, Snutch TP, Catterall WA (1992) Biochemical properties and subcellular distribution of an N-type calcium channel $\alpha 1$ subunit. Neuron 9:1099-1115.

Wong ROL, Chernjavsky A, Smith SJ, Shatz CJ (1995) Early functional neural networks in the developing retina. Nature 374:716-718.

Woodward DJ, Hoffer BJ, Lapham LW (1969a) Correlative survey of electrophysiological, neuropharmacological, and histochemical aspects of cerebellar maturation in the rat. In: Neurobiology of cerebellar evolution and development (Llinas R, ed), pp 725-741. Chicago: AMP.

Woodward DJ, Hoffer BJ, Lapham LW (1969b) Postnatal development of electrical and enzyme histochemical activity in Purkinje cells. Exp Neurol 23:120-139.

Yuste R, Peinado A, Katz LC (1992) Neuronal domains in developing neocortex. Science 257:665-669. 